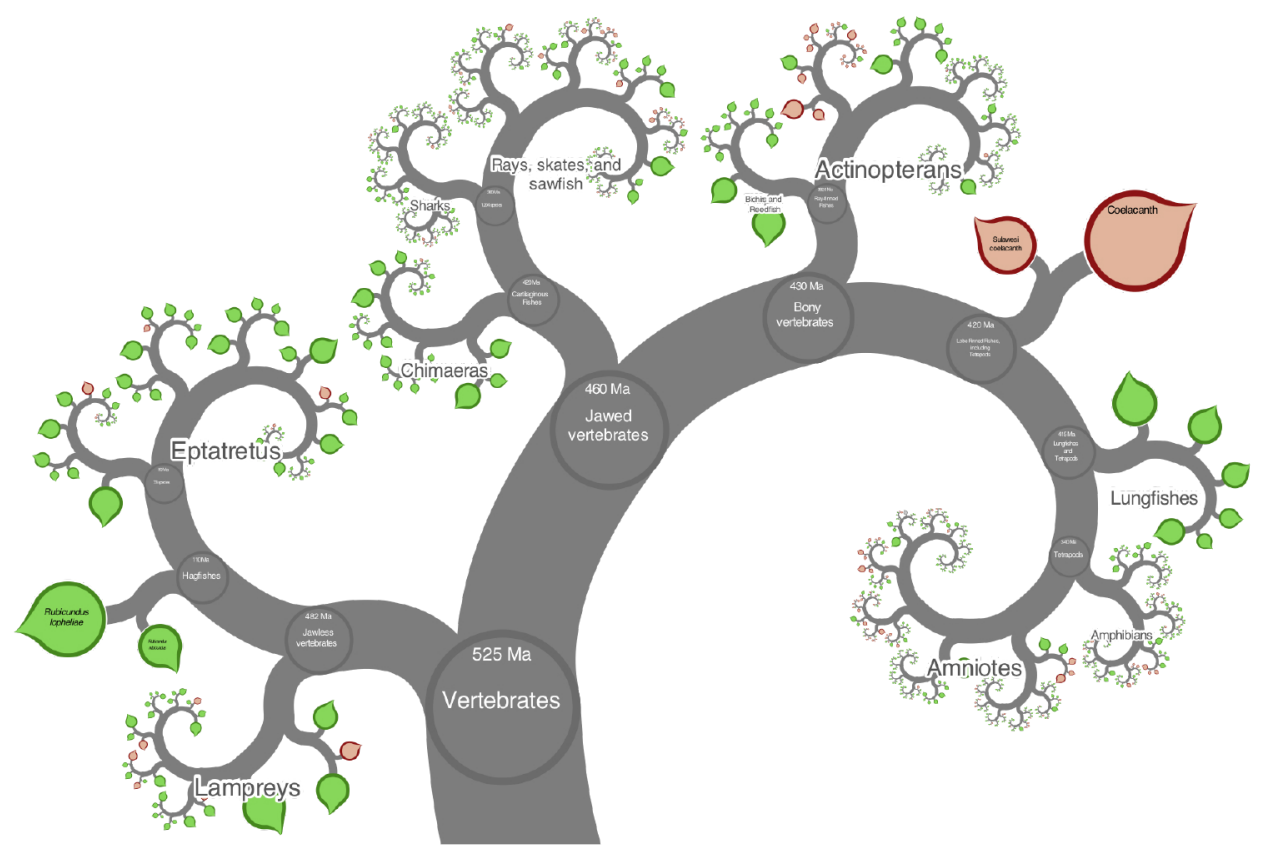

\title{
Travelling through time
}

Students' interpretation of evolutionary time in dynamic visualizations

\author{
Jörgen Stenlund
}

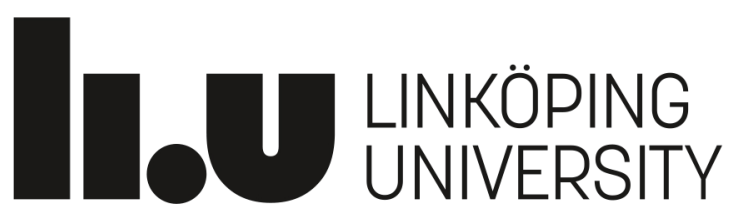


Linköping Studies in Science and Technology Education No.1833

Licentiate Thesis

Travelling through time

Students' interpretation of evolutionary

time in dynamic visualizations

Jörgen Stenlund

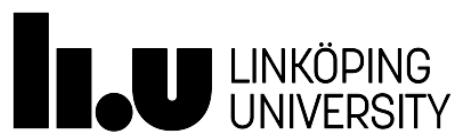

Department of Science and Technology

Linköping University, SE-601 74 Norrköping, Sweden

Norrköping 2019 
Travelling through time - Students' interpretation of evolutionary time in dynamic visualizations

(C) JÖRGEN STENLUND, 2019 (unless otherwise noted)

liu-tek-lic 2019

ISSN 0280-7971

ISBN: 978-91-7685-121-O

ISSN 1652-5051 no 105

Linköping University

Department of Science and Technology

SE-601 74 Norrköping

Printed by LiU Tryck, Linköping Sweden 2019

Cover: An image from OneZoom.org (2019)

URL: http://www.onezoom.org/life.html/@Vertebrata=801601 
Travelling through time

Students' interpretation of evolutionary

time in dynamic visualizations

By

Jörgen Stenlund

March 2019

ISBN 978-91-7685-121-0

Linköping studies in science and technology

Licentiate Thesis No. 1833

ISSN 0280-7971

Studies in Science and Technology education

ISSN 1652-5051 no 105 


\section{ABSTRACT}

Evolutionary knowledge is important to understand and address contemporary challenges such as loss of biodiversity, climate change and antibiotic resistance. An important aspect that is considered to be a threshold concept in teaching and learning about evolution is the time it involves. The history of evolution comprises several scales of magnitude, some of which are far from direct human experience and therefore difficult to understand. One way of addressing this issue is to use dynamic visualizations that represent time, for example, to facilitate teaching and learning about evolution.

This thesis investigates how students' comprehension of evolution and evolutionary time can be facilitated by visualizations in educational settings. Two different dynamic visualizations were investigated. In paper I different temporal versions of a spatio-temporal animation depicting hominin evolution were explored. The temporal information was expressed as one or several timelines along which an animated cursor moved, indicating the rate of time. Two variables, the number of timelines with different scales, and the mode of the default animated time rate (either constant throughout the animation or decreasing as the animation progressed), were combined to give four different time representations. The temporal aspects investigated were undergraduate students' ability to find events at specific times, comprehend order, comprehend concurrent events, comprehend the length of time intervals, and their ability to compare the lengths of time intervals.

In paper II, perceptions and comprehension of temporal aspects in an interactive, multi-touch tabletop application, DeepTree, were investigated. This application depicts the tree of life. The focus was on the interactive aspects, especially how the zooming feature was perceived, but also on any misinterpretations associated with the interaction. The same temporal aspects listed for paper I were also implicitly investigated.

The findings indicate that handling the problem of large differences in scale by altering the rate of time in the visualization can facilitate perception of certain temporal aspects while, at the same time, can hinder a correct comprehension of other temporal aspects. Findings concerning DeepTree indicate that the level of interactions varies among users, and that the zooming feature is perceived in two ways, either as a movement in time or as a movement in the metaphorical 
tree. Several misinterpretations were observed, for example the assumption that the zooming time in the tree corresponds to real time, that there is an implicit coherent timeline along the y-axis of the tree, and that more nodes along a branch corresponds to a longer time.

The research reported in this thesis supports the claim that careful choice, and informed use of visualizations matters, and that different visualizations are best suited for different educational purposes

Keywords: evolution, visualization, time, learning, threshold, zooming

Department of Science and Technology Linköping university SE-581 83 Linköping, Sweden 


\section{Svensk sammanfattning}

För att kunna förstå och ta ställning till utmaningar i form av exempelvis klimatförändringar, förlust av biodiversitet och antibiotikaresistens krävs kunskap om evolution. För att förstå evolution är det i sin tur viktigt att inse betydelsen av de tidsskalor som evolutionära processer omfattar. Detta utgör inte sällan ett problem vid undervisning om evolution eftersom det rör sig om tidsskalor som sträcker sig långt bortom vad vi själva kan erfara. Tidsskalor ingår i en grupp av begrepp som kallas tröskelbegrepp. Tröskelbegrepp utmärks av att de är svåra att ta till sig, men när väl förståelse uppnås så innebär det en radikal och permanent förändring av hur ett ämnesinnehåll, exempelvis evolution, betraktas. Av den anledningen är de också "enkelriktade" i meningen att den nya förståelsen är bestående

Ett sätt att bemöta problemen med att förstå tidsskalor av varierande storlekar är att använda dynamiska visualiseringar. Denna avhandling handlar just om hur elevers förståelse av evolution med avseende på tiden kan underlättas genom visualiseringar i undervisning. Avhandlingen baseras på två studier som var och en belyser evolutionär tid på olika sätt beträffande såväl innehåll som form.

I den första studien undersöktes hur olika varianter av en tidsrepresentation i form av animerade tidslinjer påverkade 144 studenters förståelse av olika tidsaspekter. Representationen av tid hade två variabler, nämligen antal tidslinjer (en tidslinje respektive 3 tidslinjer med olika skalor) och hastighet för animationen av tidsförloppet (konstant hastighet respektive avtagande hastighet när animationen närmade sig nutid). De två variablerna kombinerades för att ge fyra olika varianter av tidsrepresentation. I studien jämfördes varianterna genom att undersöka studenters förmåga kring olika tidsaspekter; hitta händelser vid specifika tider, uppfatta ordning på händelser, uppfatta samtidiga händelser, uppfatta längden på ett tidsintervall och jämföra längden av två tidsintervall.

I den andra studien undersöktes uppfattningar och förståelse av tidsmässiga aspekter hos 10 gymnasieelever med utgångspunkt från det interaktiva multi-touch-bordet "DeepTree". Det är en interaktiv visualisering av livets träd, det vill säga de fylogenetiska sambanden mellan organismer på jorden. I denna studie fokuserades de interaktiva aspekterna av visualiseringen, särskilt kring hur zoomfunktionen uppfattades av elever men också vilka missuppfattningar som var kopplade till interaktioner. Även tidsaspekterna från den första studien undersöktes. 
Resultaten från den första studien visar att det under vissa omständigheter kan vara en fördel att variera det animerade tidsflödet, till exempel genom att hastigheten på tidsflödet i animationen avtar under en speciellt händelserik period som behöver granskas noggrannare. Under andra omständigheter kan det däremot vara olämpligt att variera hastigheten för den animerade tiden eftersom det försvårar bedömningen av storleken på, och jämförelsen av, tidsintervall. Det är alltså viktigt att lärare är medvetna om vilken, eller vilka, tidsaspekter som är centrala i den specifika lärandesituationen.

Resultaten från den andra studien visar två olika sätt att uppfatta zoomfunktionen när den används i applikationen DeepTree; antingen som en rörelse i tid eller som en rörelse i det metaforiska trädet. Flera missuppfattningar av interaktionen observerades hos eleverna. Till exempel tolkade en del elever den tid det tog att zooma i trädet som att det motsvarade hur lång tid som förflöt mellan olika evolutionära händelser. Ett antal elever verkade anta att det finns en implicit linjär tidslinje längs y-axeln på trädet, och att ju fler grendelningar som fanns längs en gren desto längre tid motsvarade grenen. Generellt är de flesta tidsaspekter svåra att uppfatta för användare av DeepTree. Evolutionära träd av denna typ är dock främst gjorda för att illustrera släktskapsförhållanden, men de tidsmässiga aspekterna skulle kunna förbättras. Applikationer av den typ som DeepTree utgör har potential att erbjuda goda möjligheter till lärande även beträffande evolutionär tid men hänsyn behöver då tas just till hur tidsaspekter beskrivs. 


\section{Preface}

I did not enter biology with a specific biological interest, such as bird watching or fishing. It was more of a philosophical aspect that made me curious about biology. Questions such as where we all come from and how all of the life we encounter daily came about intrigued me. With this approach, it was natural that evolution soon became my particular fascination, since it addresses many of the ultimate "why" questions in biology.

Apart from science, I have many other interests, such as music, dance, literature and art. Common denominators for these activities are communication and creativity, and these features are very appealing to me and are probably the main reasons for my choice in becoming a teacher. In my profession as a teacher, I've had the opportunity to combine my interest for communication and creativity, which has been a driving force for me.

In the last four years, I've had the opportunity to combine several of these interests in a completely new setting: research in science education focusing on how visualizations of evolutionary time can facilitate understanding of evolution. It has been a truly marvellous experience ever since my supervisor, Lena Tibell, showed me Visualiseringscenter $\mathrm{C}$ in Norrköping for the first time, where the research group is situated. Since then, I've always looked forward to seeing Norrköping, meeting my colleagues there, and anticipating the always intense meetings.

A well-known metaphor is that "education is a journey" and there certainly are similarities between these two entities. Experiencing new aspects of life and seeing things in new perspectives are enriching in a similar way to travelling to unknown places can be. And it certainly has been a wonderful journey. All of it has not been downhill - there certainly has been some uphill travelling as well. But in the end, without any doubt, it was worth all of the effort, I'm really happy about the view from where I am now. 


\section{Acknowledgement}

First of all, I would like to thank my main supervisor Lena Tibell for all the generous sharing of your knowledge, assistance, hospitality and inspiration - it has been such a great pleasure to collaborate with you during these years. I'm also very happy to have had the opportunity to be guided by Konrad Schönborn, my co-supervisor. Your knowledgeable, always encouraging and inspiring guidance has also been invaluable. I am very grateful for all of the effort both of you have put into guiding me along the way.

I would also like to thank all of the people involved in the EvoVis project for your support, friendship and the very fruitful environment that you provide. This includes the Swedish group with Andreas Göransson, Daniel Orraryd, Gustav Bohlin, Gunnar Höst, Marta KoćJanuchta, Henry Fröcklin, Johanna Andersson, Alma Jahic Pettersson and Prof. Nalle Jonsson and the German group with Prof. Ute Harms and Daniela Fiedler. In the Swedish group, a special thanks to Henry Fröcklin, who has been an invaluable help assisting with the technical aspects of publishing the web-based animations and in assisting with video recordings. Thanks to Prof. Anders Ynnerman and to Eva Skärblom, who most certainly is an administrative genius, has most generously provided top-class support.

Thanks to Dr. Chia Shen, Harvard University and Dr. Florian Block, University of York for providing us with the opportunity to do research on the DeepTree application.

I'm also grateful to my closest colleges at the Department of Science and Technology, Bodil Sundberg, Barbro Bergfeldt, Erik Sjöstedt, Ulrika Sultan and Annica Gullberg. You have all suffered from me being grumpy and not available, complicating planning, etc. but I've always been met by a forgiving smile from you, which I appreciate very much. Ulrika Sultan has also been a great support as a PhD student, and I very much appreciated Annica Gullberg as the reader of my $60 \%$ seminar. At Örebro University I've also received valuable technical assistance from Henrik Wahlstedt, thank you for that.

Tobias Ahlin, thank you very much for your valuable assistance and tips in the development of the software used in Paper I. Two very important person who generously have offered me to use their apartment in Stockholm, in which much of this thesis was written, are Barbro and Ulf Thelander; thank you very much for that, it has been invaluable. Lars and Lena Andersson are thanked for excellent hosting, friendship and inspiration in Linköping. I also want to thank Assoc. Prof. Astrid Bulte and Prof. Doris Jorde, early readers of the proposed project. A 
special thanks to Assoc. Prof. Inger Edfors, who was a muchappreciated reader in the $90 \%$ seminar, and to Prof. Niklas Gericke who will act as the opponent during the licentiate seminar.

To all of the students who participated, I would like to address my great gratitude - without you this would never have been possible to accomplish. A person whom I am in serious debt to is Jennica Petré, due to her really kind and valuable, cooperation, making it possible to perform Paper II with students from an upper secondary school. Thank you to Andreas Larsson, who put me in contact with Jennica and with whom I've had many interesting discussions and support.

I would also like to thank Dr. James Rosindell for permission to use an image from the website OneZoom on the cover of this thesis and Scott Bjelland, Director of Communications, Turkana Basin Institute, Jamie Brightmore and Leonard Eisenberg for giving me the permission to reproduce images from websites they are responsible for.

The research was funded by Örebro University, LUN with Krister Persson as chairman, which was of fundamental importance to make this possible in combination with contribution from the department of Science and Technology at Örebro University. Furthermore, funding was also provided from the EvoVis project, Vetenskapsrådet (grant number 2012-5344) and FontD (grant 729-2013-6871), the Swedish National Graduate School in Science, Mathematics and Technology Education, which I am very happy to have attended. I am also very grateful to Dr. John Blackwell, Dr. Konrad Schönborn and Dr. David Morrison for language reviews.

Finally, I want to thank my family for all their support. First and foremost, my beloved and wonderful wife, Ulla Stenlund, who really has made a major contribution to this endeavor by always being supportive and encouraging as well as understanding. And thanks also to my daughters Agnes Stenlund and Linnea Stenlund, the flowers of my life, for being such great supporters. Linnea and Josef Laden, thank you for hosting me so many times in Linköping and Norrköping - it made my studies so much richer and joyful.

Latorp January 2019 Jörgen Stenlund 


\section{List of papers}

Paper I

Stenlund, J.I. \& Tibell, L.A.E. (2018). Visualizing macroevolutionary timescales - Students' comprehension of different temporal representations in an animation (Manuscript re-submitted to Evolution: Education and Outreach)

Paper II

Stenlund, J.I., Schönborn, K.J. and Tibell, L.A.E. (2018). Zooming in time - Student interaction with a dynamic Tree of Life (Manuscript)

\section{Authors contribution}

Paper I was a collaborative work by the authors. The idea for the project developed from my thoughts about evolutionary time, and the animations used in the study were all created by me, but ideas for design of the animation and the design of the study were discussed by both authors. The data collection was done by me, but the analysis was a collaborative work by both authors. I wrote the original drafts of the manuscript, but it was revised and modified by both authors.

Paper II was a collaborative work by the authors. The study design and interview protocol were developed in discussions between the authors. The pilot study, clinical interviews and transcripts were performed by me, but the analysis was performed cooperatively by all authors. The original draft of the manuscript was produced by me but was later revised and modified by all authors. 


\section{Table of Contents}

Svensk sammanfattning

Preface

Acknowledgement

List of papers

Authors contribution

Table of Contents

1. Introduction

vii

ix

$\mathrm{x}$

xii

xii

xiii

1.1 Structure of the Thesis 17

1.2 Purpose of the Thesis 18

1.3 Positioning of the Thesis 18

2. Theoretical Framework $\quad 21$

2.1 Evolution $\quad 21$

2.1.1 Evolutionary theory $\quad 21$

2.1.2 Hominin evolution $\quad 22$

2.1.3 Teaching and learning about evolution $\quad 24$

2.1.4 Threshold concepts in learning biology 25

2.2 Time and evolution $\quad 25$

2.2.1 The nature of time $\quad 26$

2.2.2 The importance of long time spans in evolution $\quad 26$

2.2.3 Conceptual and reasoning difficulties related to evolutionary time 27

2.2.4 Research on temporal comprehension of evolutionary time $\quad 28$

2.3 Visualizations

2.3.1 Visualization and learning $\quad 29$

2.3.2 Visualizing time - an historical perspective $\quad 30$

2.3.3 Different visual representations of evolutionary time $\quad 31$

2.3.4 Phylogenetic trees 34

2.3.5 How students understand time in dynamic, spatiotemporal visualizations and phylogenetic trees $\quad 36$

2.4 Theoretical Lenses for Considering Students'

Interpretation of Evolutionary Time 39

2.4.1 Threshold concepts in science learning 39

2.4.2 Time metaphors and embodied learning $\quad 39$

2.4.3 Multimodal learning and cognitive load in learning with visualizations 41

2.4.4 The role of visualization design on learning $\quad 41$

3. Aims and Research Questions

41

4. Methods 
4.1 Brief Description of the Visualizations Investigated in the Research

4.1.1 The animation used in paper I 45

4.1.2 The DeepTree application $\quad 47$

4.2 Study Context and Data Collection $\quad 48$

4.2.1 Study context $\quad 49$

4.2.2. Data collection $\quad 50$

4.3 Analysis 55

4.3.1 Categorization of response in paper I 55

4.3.2 Emergent themes from the interviews reported in paper II $\quad 56$

4.3.3 Analysis of interactions in paper II $\quad 57$

4.4 Reliability and Validity $\quad 57$

$\begin{array}{cc}\text { 4.5 Ethical Considerations } & 58 \\ \text { 5. Findings } & 59 \\ \text { 5.1 Paper I } & 59\end{array}$

5.2 Paper II 60

5.3 Comparison of Findings in Both Papers 61

6. Discussion and Implications 65

6.1 Animated Timelines in Visualizations
of Evolutionary Time

6.2 Aspects of Temporal Representations in Touch Sensitive Interfaces 68

6.3 The zoom aspect of DeepTree 68

6.3.1 The time aspect of DeepTree 69

6.3.2 Misinterpretations induced by DeepTree $\quad 70$

6.4 Implications for Teaching and Learning about Evolution 71

6.5 Summary and Conclusion $\quad 72$

$\begin{array}{ll}6.6 \text { Future Research } & 73\end{array}$

7. References

75 


\section{Introduction}

This thesis is about how students' comprehension of evolution and evolutionary time can be facilitated by visualizations in educational settings. It is an investigation into how different visual representations are perceived, and how students' understanding is expressed in response to tasks and questions. The dissertation has a science education approach, concerned with teaching and learning about evolution with a particular focus on evolutionary time.

Different theoretical frameworks emphasize different aspects of learning, from cognitive processes within individuals to participation in different cultures (Wallin, 2004). Most of the learning theories accounted for in this thesis are based on a constructivist perspective and focused on individual learning - that is, how individuals construct their understanding of the world. This is not to say that all constructions of the world are equally correct. On the contrary, and in line with Sjøberg (2010), I want to emphasize that I believe there is a mindindependent world, and that science has made progress and refined our understanding of it. An example of this is the theory of evolution, which is the unifying principle in biology (Dobzhansky, 1973), explaining both the unity and diversity of biological organisms.

Evolution is an important subject from different perspectives, and for several reasons. From a societal point of view there are economic, utilitarian, democratic and moral reasons (Driver, Leach, \& Millar, 1996). From a personal perspective, evolution is essential to understanding our own history, and to be able to formulate informed opinions about some of the more challenging contemporary problems, such as loss of biological diversity and antibiotic resistance. These are all reasons to promote efforts to improve teaching and learning about evolution, which is within the domains of science didactic to which this thesis adheres. The specific didactic perspective and theme in the thesis is teaching and learning evolutionary time using visualizations.

A most essential implication of evolution is that it can lead to "the development of new types of living organisms from pre-existing types by the accumulation of genetic differences over long periods of time" (Lawrence \& Henderson, 2011). This occurs over long periods of time (from thousands, to billions of years), which is thus of central interest in this dissertation.

The meaning of understanding evolutionary time as used in the context of this thesis is: (i) the ability to comprehend important temporal aspects, such as relative order, concurrency and duration of events and processes in timespans extending to the origin of life, and 
(ii) the ability to relate different magnitudes of temporal scales (Catley \& Novick, 2009; Cheek, 2013b; Dodick, 2007; Dodick \& Orion, 2003b; Hidalgo, Fernando, \& Otero, 2004; Libarkin, Kurdziel, \& Anderson, 2007; Trend, 2000, 2001).

Visual metaphors of time, such as timelines and evolutionary diagrams with temporal information, have been used more than 150 years, but new technologies offer new and extended ways of experiencing a phenomenon that was previously challenging to represent. The possibility to communicate dynamic events and processes, as well as offering interactivity, is now afforded in a multitude of applications, for example in many dynamic visualizations. The term dynamic visualization will be used here to denote any visualization that is not static, including animations and simulations that dynamically represent and display processes that change over time (Ainsworth, 2008).

This thesis concerns the time during which living organisms are known to have existed; that is, time spans covering up to 3,5 billion years (Schopf, 1993). The terminology for such vast periods of time include terms such as deep time, which is primarily used in earth sciences to characterize time spans covering the age of the earth 4,5 billion years (Allegre, Manhes, \& Göpel, 1995), evolutionary deep time, and macroevolutionary time. The term macroevolution is more frequently used in particular contexts, but I find it a bit problematic since it implicitly implies an ontologically different type of evolution, microevolution. Thus, it is not used in this thesis. I have chosen to use the term evolutionary time when referring to what, in other contexts, would be called deep time or macroevolutionary time, even though evolutionary time can also include short time spans which are only briefly mentioned.

To understand evolution it is necessary to comprehend evolutionary time (e.g. Catley \& Novick, 2009; Dodick, 2007; Trend, 2001), and dynamic visualizations offer new ways to teach and learn about time in evolution. Therefore, the subject of this thesis is how these visualizations can facilitate understanding of evolutionary time from an educational perspective. The studies both involve an investigation of interactive visualizations that endeavor to convey events unfolding in evolutionary time, but illuminating different aspects. Paper I focuses on evolutionary time in relation to geographical aspects of the appearance, dispersal and disappearance of hominin species, whereas paper II focuses on evolutionary time in relation to the development of relatedness among organisms since the beginning of life. Both papers discuss the implications for the design of visualizations of evolutionary time and their use for educational purposes. 


\subsection{Structure of the Thesis}

This thesis consists of three parts: two separate papers and a comprehensive summary. This introductory chapter includes a description of the structure (1.1), purpose (1.2) and positioning (1.3) of the thesis.

The second chapter covers the theory necessary to provide an account of the background to the papers. Since this thesis is concerned with science didactics, the necessity to include several theoretical frameworks is inherent (Sjøberg, 2010). Moreover, visualizations of evolutionary time require even more theory to be included. So, the chapter has four parts.

The first part starts by defining the scientific concept of evolution. Section 2.1 covers a series of subsequent and interrelated parts. The first part describes the theory of evolution (2.1.1), hominin evolution (2.1.2), and teaching and learning about evolution (2.1.3 and 2.1.4). The chapter ends by acknowledging that evolutionary time is a crucial concept to understand.

The second part of chapter two is about the nature of time (2.2.1), the importance of long time spans in evolution (2.2.2), and the challenges in learning about time (2.2.3 and 2.2.4).

The third part of chapter two concerns visualizations, and starts with an account of visualizations and learning in general (2.3.1) followed by an historical account of how time has previously been visualized (2.3.2). Then several variants of representations are exemplified, covering evolutionary time in general (2.3.3). In the subsequent text, a brief description of phylogenetic trees follows (2.3.4), which is an archetypical representation of evolution. The third part of chapter two concludes with how students understand different visual representations of evolution, with a particular focus on the types used in the thesis (2.3.5).

In the fourth and concluding part of chapter two, theoretical lenses for considering students' interpretation of evolutionary time are accounted for, starting with threshold concepts in science learning (2.4.1), time metaphors and embodied learning (2.4.2), multimodal learning and cognitive load in learning with visualizations (2.4.3), and ending with the role of visualization design on learning (2.4.4).

In chapter three the aims and research questions are described.

Chapter four provides a brief description of the visualizations (4.1.1 and 4.1.2), the study context (4.2.1), and data collection (4.2.2). Methodological issues concerning the data analysis in both studies are described (4.3) followed by aspects of validity and reliability (4.4), and the chapter concludes with an account of ethical considerations (4.5). 
In chapter five the findings are described, first regarding each paper and then in light of each other.

Chapter six discusses the findings, including implications for education and research concerning ways to visually communicate evolutionary time.

\subsection{Purpose of the Thesis}

In order to gain a perspective of our role in, and responsibility for, the biosphere, it is necessary to understand the background and position of our own species in evolutionary history. As Catley (2006) puts it,

"The sense of humility gained through an appreciation of the kinship of all life is a vitally important component in nurturing a stewardship ethic for a planet moving ever deeper toward ecological collapse." ( $\mathrm{p}$. 781).

Climate change and loss of biological diversity are examples of important issues that require knowledge about evolution and evolutionary time in order to fully appreciate the consequences, especially to understand the magnitude of the rate of change and to compare the time frame involved in opposing events, such as speciation.

However, prior research has shown that understanding, or even accepting, the scientific definition of evolution has proven to be a significant challenge in many instances (Smith, 2010a, 2010b). One of the challenges that learners face when learning about evolution is grasping the vast time periods involved in evolution (Catley \& Novick, 2009; Dodick, 2007). One way of addressing this problem is through visualizations. The purpose of this thesis is to provide knowledge about how different and novel ways of visualizing evolutionary time can facilitate teaching and learning about evolution. It is directed to teachers and students, as well as designers of visualizations and the interested public.

\subsection{Positioning of the Thesis}

This thesis is positioned in the field of science didactics with a particular focus on teaching and learning evolutionary time using visualizations. Due to the nature of science didactics, which is a conglomerate of two areas, science and pedagogy (Sjøberg, 2010), the necessity to include several theoretical frameworks is inherent. Furthermore, visuali- 
zations of evolutionary time require even more theory to be included. Thus, in addition to scientific and pedagogical theories, theoretical frameworks from Cognitive Science, Visual Communication and Geographical Information systems (GIS) are relevant in this context as well. 



\section{Theoretical Framework}

Several theoretical frameworks that form the underpinnings of this research will be presented in the following text. Three different aspects, namely evolution, time and visualizations, will first be accounted for separately and then merged, and discussed in the context of teaching and learning about evolutionary time using dynamic visualizations.

\subsection{Evolution}

There are several definitions of Evolution, which vary slightly - depending on the context, different aspects can be stressed. The implications of evolution are included in some definitions, for example that evolution can lead to "the development of new types of living organisms from pre-existing types by the accumulation of genetic differences over long periods of time" (Lawrence \& Henderson, 2011). Another example with a slightly different definition is offered by Sanders and Bowman, (2016): "Any change in the genetic characteristics of a population, strain, species over time". In both of these the importance of evolutionary time is highlighted. A commonly used definition of evolution is "any change in the frequency of alleles within a gene pool from one generation to the next." (Curtis \& Barnes, 1989, p.974), which only pinpoints the most essential short-term process and omits all other aspects.

\subsubsection{Evolutionary theory}

The scientific theory of evolution by natural selection was proposed by Charles Darwin (1859) and Alfred Russel Wallace, and later on complemented with concepts from Mendelian genetics and population genetics in the notion of "the modern evolutionary synthesis" (Huxley, 1942). In addition to natural selection, factors such as mutation, genetic drift and gene flow have also been shown to affect evolution. The foundation for the modern evolutionary synthesis has been summarized in different ways by different authors, depending on the context of communication (e.g. occurring among experts or pupils in a high school class). Mayr (1982) formulated an assembly of "facts" and inferences that also have guided later authors see Table 1. 
Table 1. The facts and inferences formulated by Mayr (1982)

Facts

i) All populations have the potential to grow at an exponential rate

ii) Most populations reach a certain size, and then remain fairly stable over time
Inferences

1. Not all offspring survive to reproductive age, in part because of competition for natural resources. iii) Natural resources are limited

iv) Individuals in a population are not identical, but vary in many characteristics

v) Many of the characteristics are inherited.
2. Survival is not random: individuals with characteristics that provide them with some advantage over others in their particular environmental situation will survive to reproduce (to a higher degree), whereas others will not (or to a lesser degree)

3. Populations change over time as the frequency of advantageous alleles increases. These can accumulate over time to result in speciation.

Later, and additional, frameworks illuminate complementary aspects of the modern evolutionary synthesis, such as the fundamental importance of random mutations, the role of cumulative evolution, the distribution of species biogeography and macroevolution (e.g. Andersson \& Wallin, 2006; Ohlsson \& Bee, 1992; Shtulman, 2006).

These facts and inferences, complemented by additional empirical support from a huge variety of sources, ranging from fossils, comparative anatomy, biogeography to molecular biology, serve as the basis for the theory of evolution, underpinning all biological sciences.

\subsubsection{Hominin evolution}

Based on the fossil record and comparisons of human DNA with the DNA of our closest relatives (chimpanzees and bonobos), the last common ancestor we share lived approximately 6 to 7 million years ago (abbreviated mya). Species that exist, or have existed on our lineage (organisms allied by common descent) after the split from the chimpanzee and bonobo line are termed hominins (Pontzer, 2012). Thus, hominins include our species and all extinct species along that branch. 
Characteristics of species belonging to the hominin branch are that they have bipedal walking and small and blunt canines.

The following text is a summary of the present knowledge concerning spatio-temporal aspects of hominin evolution, which is the subject matter of paper I.

Hominin evolution is a dynamic area of study, and recent research has unveiled much new knowledge from paleontological findings and information based on molecular biology. These two areas cover varying time spans and give rise to qualitatively different information.

The oldest fossils known today that show indications of these features can be divided into three groups: Sahelanthropus found in Chad (6-7 mya), Orrorin (6 mya) found in Kenya, and Ardipithecus found in Ethiopia (4,4-5,8 mya). All of these fossils bear signs of bipedal walking.

Following the three oldest known groups of hominins, the genus Australopithecus appears in the fossil record. The oldest species so far discovered in this genus is $A$. anamensis (approximately 4,2 mya) from Kenya, but the best known species are $A$. afarensis from East Africa (3,6-2,9 mya) and A. africanus from South Africa (3,2-2.0 mya). The genus Australopithecus persisted for nearly 3 million years.

The genus Homo is first represented in the fossil record 2,8 mya by the finding of a lower jawbone in Afar, Ethiopia (Villmoare et al., 2015). $H$. habilis is associated with simple stone tools (Blumenschine et al., 2003). The successor of $H$. habilis, $H$. erectus, became very widespread and persisted for almost 2 million years (1,9-0,1 mya). This species has been found in Africa, Europe and Asia. Approximately 700 ooo years (abbreviated kya) ago $H$. erectus gave rise to $H$. heidelbergiensis in Africa (Rightmire, 2009). H. heidelbergiensis later spread to Europe, where populations of this species evolved to $H$. neanderthalensis approximately 250 kya (Hublin, 2009).

Recent research extends the origin of $H$. sapiens back to more than $315 \mathrm{kya}$, either from $H$. heidelbergensis or $H$. rhodesiensis (Hublin et al., 2017). H. sapiens spread and reached Europe by 100 kya, and eventually with a global distribution (DeGiorgio, Jakobsson, \& Rosenberg, 2009). $H$. neanderthalensis became extinct approximately 30 kya, but DNA from fossils indicate occasional interbreeding between $H$. sapiens and $H$. neanderthalensis thereafter (Fu et al., 2015; Green et al., 2010).

To avoid information overload in the animation used in paper I, some of the species, for example, $H$. floresiensis (Brown et al., 2004) and $H$. naledi as well as some of the species included in the genus Paranthropus, were omitted from the animations. 


\subsubsection{Teaching and learning about evolution}

Much research has confirmed that teaching and learning about evolution can be very challenging. Not only do teachers need to understand the complex factors involved in evolutionary processes, but also how to communicate ideas that are counter-intuitive and even repulsive to many people (Smith, 2010b). To list a few of the reasons: (i) intuitive thinking, such as essentialism and teleological reasoning, offers erroneous ontological perspectives; (ii) it is hard to grasp the complexity that results from interacting factors leading to natural selection; and (iii) the involvement of large (and/or small) numbers in terms of probabilities, spatial scales and temporal scales makes the theory of evolution abstract and to many people counter-intuitive (e.g. Mayr, 2007; Nehm \& Reilly, 2007; Mayr, 1982). Furthermore, religious opposition can hinder students from accepting a scientific view of evolution (e.g. Basel, Harms, \& Prechtl, 2013; Billingsley et al., 2016; Yasri \& Mancy, 2014).

Of particular interest in this thesis are those difficulties associated with understanding evolutionary time, which is important to understand evolution itself. Two central aspects pointed out by Catley and Novick (2009, p. 313) are: understanding evolutionary time enables students to see "that over vast periods of time very improbable events do indeed occur; and that very small, seemingly insignificant changes do accumulate, often with major impacts" (p. 330). Moreover, knowledge about evolutionary time is one of the primary problems for many people who do not accept biological evolution. For these reasons, Catley and Novick (2009, p. 313) propose that several important events in evolutionary time should be included in a teaching curriculum. Not only does understanding of evolutionary time provide a temporal framework in which it is possible to situate, relate and compare events and processes, but it also provides a basis for understanding how crucial time is in the complexity of factors leading to evolution.

Evolutionary events do not only involve long time periods. In small populations and in organisms with short generation time, evolutionary processes can occur more quickly, but evolution leading to complex organisms such as mammals requires vast time spans. The primary source of genetic variation is mutations, which occur instantaneously, but according to the definition initially stated in this chapter new mutations need to spread into future generations before evolution can be said to have occurred. Comprehending very short timespans has proven to be even more difficult than very long time spans (Lee et al., 2011), although this is a problem that this thesis will not elaborate on. 


\subsubsection{Threshold concepts in learning biology}

Meyer and Land (2005) introduced the notion of threshold concepts, a framework that is expected to provide teachers and students with a useful heuristic to confront conceptual difficulties in many different subjects. It has also been introduced in the teaching and learning of science, among other things, by Ross et al. (2010), who proposed several threshold concepts in biology and evolution; for example, randomness, probability, spatial and temporal scales. These concepts are often abstract and incorporate tacit knowledge, and need to be taught explicitly (Tibell \& Harms, 2017). Since temporal scales are included among the threshold concepts, this framework is briefly introduced here, as a background and rationale for doing this research, since evolution comprises temporal scales of several magnitudes.

Prior research has recognized the importance of, and problems associated with, teaching and learning about subjects where large differences in scale are involved (Catley \& Novick, 2009; Lee et al., 2011). In the case of teaching and learning evolution, temporal scales are relevant and important. Threshold concepts will be further discussed in section 2.4.1.

\subsection{Time and evolution}

In this section the role and importance of time in evolution will be presented. However, it is very important to be aware that time in evolution is related to, and is measured in, generation times for organisms, since evolution refers to "change in the frequency of alleles within a gene pool from one generation to the next." (Curtis \& Barnes, 1989, p.974). Thus, generation time is a decisive factor for the rate of evolution as measured in absolute time. Organisms such as bacteria usually have a short generation time, which explains their relatively high rate of evolution in terms of antibiotic resistance (Bohlin, 2017), whereas evolution in organisms with a long generation time (e.g. elephants) in general requires much longer time. Since the studies of this thesis involve complex organisms with long generation times, the term evolutionary time will mainly be used for time periods comprising thousands or millions of years, notwithstanding the fact that evolution can occur much faster, under certain circumstances and in certain organisms such as bacteria. 


\subsubsection{The nature of time}

Time is an abstract and elusive concept difficult to define. This was pinpointed by St. Augustine, Bishop of Hippo in his autobiographical work "Confessions in Thirteen Books" written ca. AD 400:

"What then, is time? I know well enough what it is, provided that noone asks me; but if I am asked what it is and try to explain, I am baffled"

Can time be separated and isolated from sequences of events? Does time travel, or is it us who travel in time? If so, in which direction? People will provide various answers to these questions, since the perception of what time is differs between different individuals. As Feeney (2007) express it: "In any society individuals are liable to inhabit different frames of time, often simultaneously - cyclical or recurrent, linear, seasonal, social, historical."

Whether it is possible to conceive of time except in terms of metaphors is doubtful (Ault, 1981; Boyd-Davis, 2012; Lakoff \& Johnson, 1999). Regardless of whether time exists as a separate entity or not, it is conceived of in metaphorical terms and a commonly used metaphor is time mapped to space (Boroditsky, 2000; Gentner, 2001).

\subsubsection{The importance of long time spans in evolution}

Charles Darwin realized that evolutionary time, that is, time periods including spans of millions of years is a prerequisite for evolution to proceed, and end up with such highly complex organisms as for example orchids or eagles. The pivotal role of time in evolution is illustrated by the influence that Charles Lyell's book "Principles of Geology" (Lyell \& Deshayes, 1830) had on Darwin's idea. Darwin read the book during his voyage on the ship Beagle. Lyell claimed that the earth's crust had been formed by natural laws, still current today, a view that implied vast periods of time in which the slow events had occurred, thus extending the age of the earth considerably compared to the prevailing beliefs during the 1830s. It made it possible for life to have evolved slowly by means of accumulated small changes. To Darwin, an ancient earth was a prerequisite for his theory.

The fundamental importance of such vast time periods made Darwin write in "The Origin of Species" that anyone who could not "admit how vast have been the past periods of time, may at once close this volume" (Darwin, 1859). The reason for this is that gradual evolution as proposed by Darwin (1859) is founded on cumulative evolution, which 
requires several generations and long periods of time. That is to say, small changes that accumulate in a direction favoured by natural selection.

Time to allow many generations is also an important part in the complexity of factors that together make up the basis for the process of evolution. This complexity involves differential survival due to random heritable genetic variation, of which certain variants are favourable under the prevailing circumstances. In eukaryotic cells (the kind of cells protozoa, fungi, plants and animals have, which contains a nucleus and organelles), the mutation frequencies in specific positions on a chromosome (e.g. the position of a gene) are usually very small, but these improbable occurrences can be counteracted by large populations and long periods of time (i.e. many generations), which not only makes evolution possible but inevitable. Furthermore, time is also required in order to spread and "fixate" a mutation in a population (i.e. for it to become established in the gene pool), as well as becoming extinct.

\subsubsection{Conceptual and reasoning difficulties related to evolutionary time}

There are several reasons for not understanding, or even accepting, the concept of evolutionary time. Both cognitive and religious reasons can hinder a scientific view (Smith, 2010b). One reason is that the concept of time is very abstract and needs to be addressed in metaphorical ways (e.g. as distances, calendars, clocks etc.).

Another reason is that evolutionary time encompasses scales which are far divorced from direct human experience which makes the concept even less concrete (Catley \& Novick 2009) and prone to be misunderstood. An example of this is the effect called "the compression effect" coined by Longo and Lourenco (2007), which refers to the phenomenon that subjects tend to tweak very big, and very small, numbers so that large numbers are underestimated and small numbers are overestimated towards the range of human experience. Catley and Novick (2009) showed that the compression effect could be revealed when subjects estimated durations for large temporal magnitudes.

A third reason is that evolutionary time comprises scales of various magnitudes, and students need to learn strategies for how to relate different temporal scales. This can be done in different ways, for example by using the full magnitude of one scale and linking it to a fraction of another scale, in order to relate the two. This is a strategy called bootstrapping, which is used for example in paper I, in animation B and D where several different timelines of different scales are related. Estab- 
lishing other kinds of temporal references as hallmarks for comparisons is another feasible and complementary strategy to relate different scales (Lee et al., 2011).

A different source for "non-scientific" conceptions is based on theological grounds. Various religions have different narratives regarding genesis and the origin of life, but very few refer to temporal magnitudes comparable with evolutionary time scales. For example, the earth is considered to be 6000 years old by young earth creationists (Heaton, 2009), and since evolutionary time is a necessity, especially for the evolution of more complex life forms, this is a fundamental issue.

\subsubsection{Research on temporal comprehension of evolutionary time}

Dodick and Orion (2003b) divide research performed in science education concerning temporal understanding into two groups: studies based on events comprised in evolutionary time (primarily relative and absolute order of events), and studies based on logical temporal reasoning. Among the event-based studies, Trend's investigations among students of different ages and primary teachers (Trend, 1998, 2001a, 2001b) are notable. In the group of logical-based studies, an early contribution regarding time cognition was made by Piaget (1969). He claimed that young children's conception of time is related to motion. Building on this notion, Ault $(1981,1982)$ performed seminal research regarding students' comprehension and reconstruction of geological strata. Ault (1981) claimed that a child's imperfect conception of conventional time was not a major obstacle for understanding geological events, which has been opposed by later research (e.g. Cheek, 2013a). Furthermore, Dodick and Orion (2003a, 2003b) have criticised the emphasis on the notion of time conceptualized as motion in the work of Ault (1981). Later research has focused other cognitive aspects, for example the importance of understanding large numbers and subject matter knowledge (Cheek, 2010, 2012; Clary, Brzuszek, \& Wandersee, 2009). 


\subsection{Visualizations}

\subsubsection{Visualization and learning}

Visualizations play an important role in science as well as in science education. Learning science requires both the understanding of external representations and the ability to form inner, mental visualizations (Gilbert, 2005). For this reason, Gilbert (2005) claims that it is important that students become metacognitively capable with respect to visualizations. This means knowing the codes of representations, being aware of what strengths and weaknesses representations have, and being able to move between modes of representations (e.g. visual, concrete and verbal). Lacking these three abilities will impair the potential to learn science.

Considering the importance of visualizations in science and education, it is hardly surprising that the number of publications regarding visualizations in science education increased very much during the decades either side of the millennium shift. However, there is still a lack of consensus concerning the definition of what a visualization is, let alone what constitutes a "good" visualization.

In a comprehensive overview, Phillips, Norris, and Macnab (2010) acknowledge 28 definitions of the term visualization in the literature from 1974 to 2009. This rich variety of definitions is partly due to different referents of visualizations - they can refer to external physical objects such as illustrations and animations, internal mental objects (e.g. mental scheme and mental representation), and various cognitive processes where visualizations are interpreted to make meaning. Thus, the term visualization can be expressed as a noun (an object) as well as a verb (an activity). According to Phillips, Norris, and Macnab (2010) visualizations are used for two main types of activities: either as a complement to other means of teaching, or as learning or as a tool to solve problems (i.e. for understanding and for analysis respectively). Of course, these functions are not mutually exclusive and some visualizations fulfil both.

Informed use of visualizations requires a comprehensive theory of picture meaning, which is not yet available according to Phillips, Norris, and Macnab (2010). However, two crucial aspects need to be considered in the use of visualizations in educational settings: knowledge about the visualized objects, and the abilities needed to interpret the information on behalf of the user (Ainsworth, 1999). 
Dynamic visualizations have to be well designed, for example by taking into account aspects such as relevance to the learning objective, complementarity with textual information, duration, and simplicity (Phillips, Norris, \& Macnab, 2010). Moreover, animations should be guided by principles of perceptual organization, such as grouping (proximity, similarity etc.), and figure-ground organization, such as size and symmetry (Pinna, 2010). However, the learner's preknowledge and abilities in terms of subject knowledge and visual literacy are of equal importance (Schnotz, 2002; Vekiri, 2002).

Real world educational settings are usually complex, and the learning outcome is dependent on several factors, including the relevance and/or design of the visualization, the learner's motivation, prior subject knowledge and visual literacy, as well as the learning context (e.g. scaffolding) arranged by the teacher. Generally, visualizations used in education are made by, and often for, experts, and chosen by teachers. Thus, it is important to remember that students differ both concerning subject knowledge and visual literacy (Linn, 2003; Matuk \& Uttal, 2018). Phillips, Norris, and Macnab (2010) summarize this in three recommendations to teachers: carefully select level-appropriate visualizations, prepare the students before performing the visualization activity, and assess the outcome to ensure the learning outcome.

\subsubsection{Visualizing time - an historical perspective}

The design of most modern timelines can be tracked back to the mid$18^{\text {th }}$ century (Boyd-Davis, Bevan, \& Kudikov, 2013). By that time charts based on a uniform scale first appeared, capable of communicating not only relative order but also relations between intervals could be visually perceived. Preceding charts only accounted for chronology, omitting information about durations.

Despite the vital importance of a uniform timescale, they also have disadvantages. One reason is that oftentimes there is a need to switch between overview and detail. Another reason is the problem of uneven distribution of events, which can create problems in visual communication (Boyd-Davis, Bevan, \& Kudikov, 2013; Vít \& Bláha, 2012). Ironically, this was reinforced by the contemporary endeavors to envision the full history since the creation at the same time, as new ideas and theories prolonged the age of the earth very much.

Based on theological grounds, the prevailing belief until the latter half of the $18^{\text {th }}$ century in Europe was that the age of the earth was a few thousand years old. Opposition to this view became more frequent, and in the late 1700s James Hutton (1726-1797) coined the term "deep time" to refer to the concept of geologic time, i.e. the history of earth in 
terms of millions (and even billions) of years. Since many evolutionary processes occur very slowly, the relevant timescales often involve deep time. Later scientific discoveries prolonged the age of the earth successively until today's estimate of 4,5 billion years (Allegre et al., 1995).

\subsubsection{Different visual representations of evolutionary time}

There is a huge variety of different visualizations of evolutionary time. The problem is often how to incorporate details at different scales, and how to relate the different scales in a way suitable for the intended learning situation. Depending on the resources available for the designer, the teacher and the learner, the range of possible representations of evolutionary time is very different. Without aiming to give an exhausting account for currently available visualizations of evolutionary time, a number of categories of currently available visualizations are presented below.

1. Analog representations in "real life" in the form of spatial distances, for example along a corridor or a toilet roll with labels of events

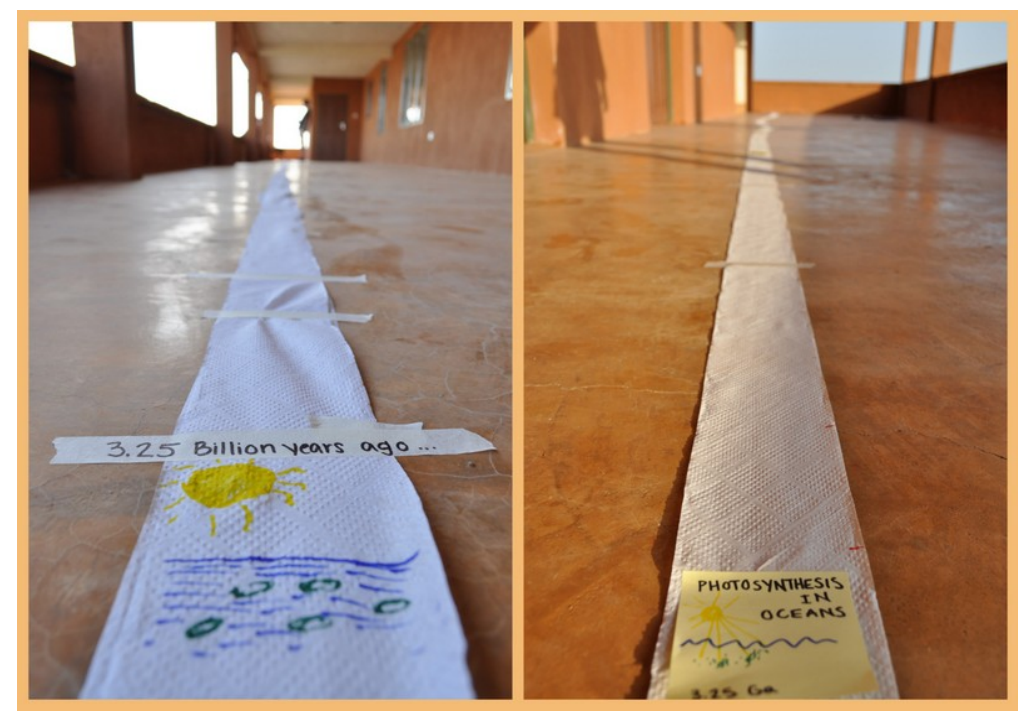

Figure 1. The toilet paper timeline (reproduced with permission from Turkana Basin Institute). By Katarina Warren February 26th, 2014. Available at http://www.turkanabasin.org/2014/o2/toiletpaper-timeline/ 
2. Analog or digital 2D non-interactive representations (i.e. different kinds of images). This category includes images of timelines, calendars and spirals

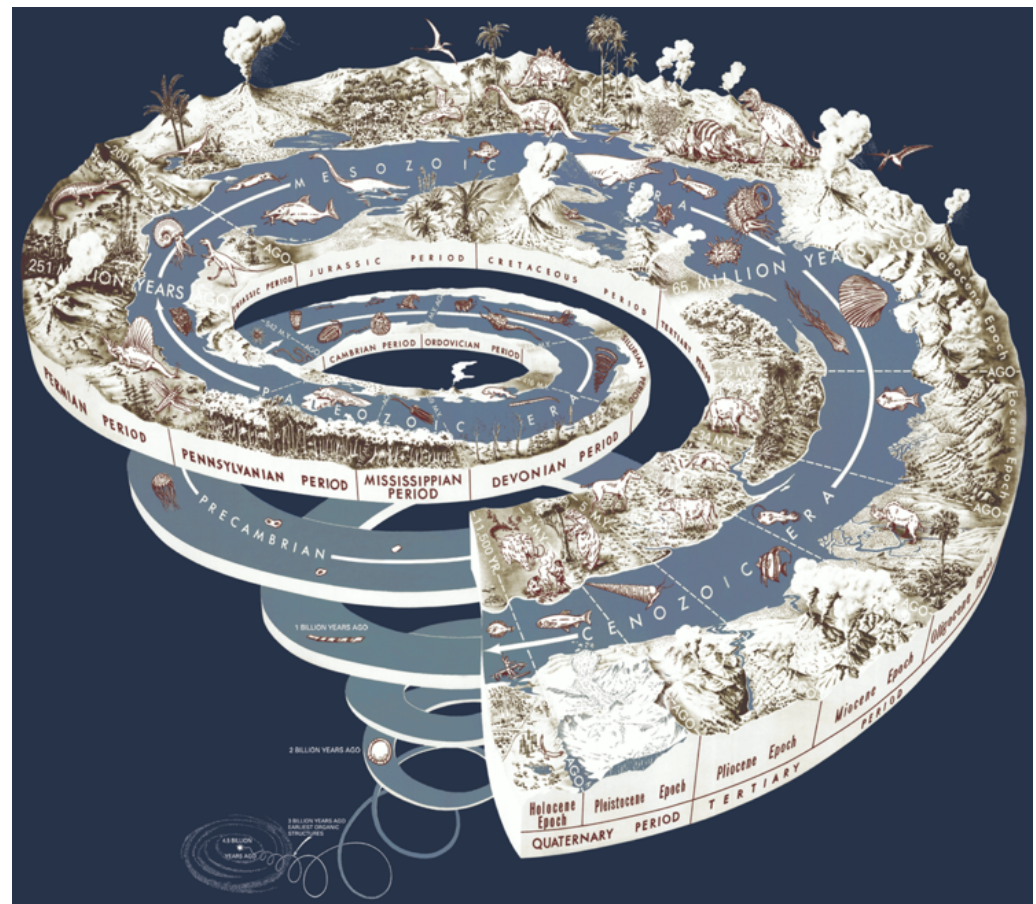

Figure 2. The geological time spiral. Produced by Graham, Joseph, Newman, William, and Stacy, John, 20o8, U.S. Geological Survey General Information Product 58, poster, 1 sheet. Available online at http://pubs.usgs.gov/gip/2008/58

3. Digital and interactive representations that change appearance in response to actions from the user. One example is the analogy of a clock. A dynamic version of this is found at http://deeptime.info in which hovering over any of the labels 


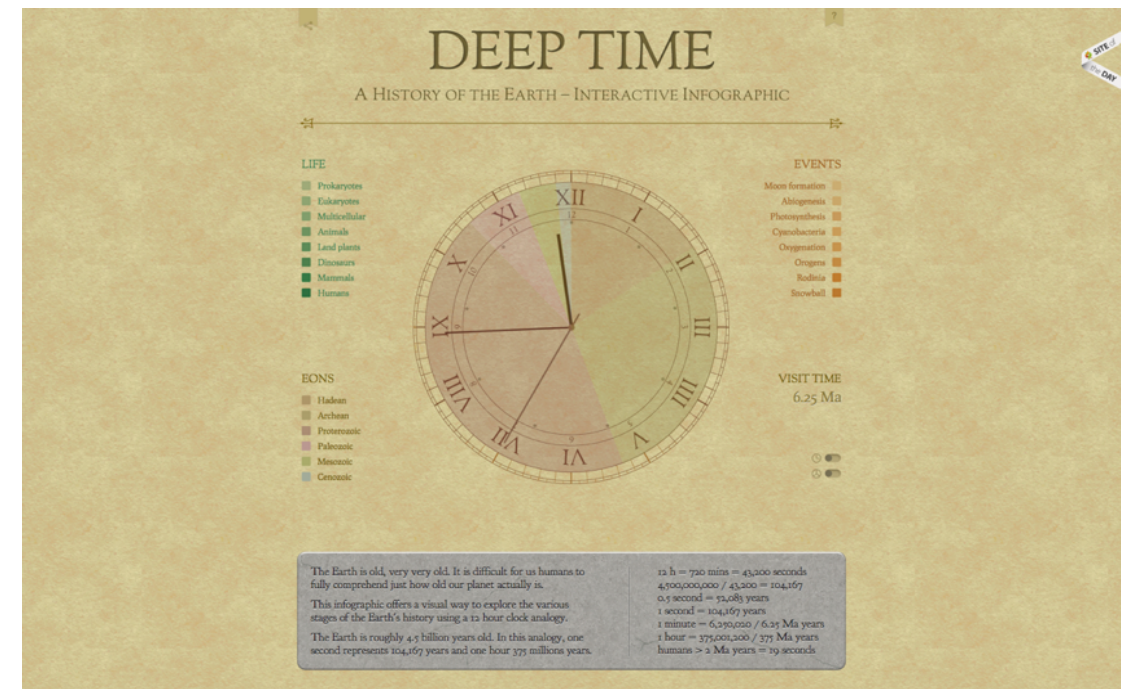

Figure 3. The Deep time clock. produced by and reproduced with permission from Jamie Brightmore. Available on http://deeptime.info

surrounding the "deep time clock" will elicit a feedback with specific information. Another interactive web based application is the Evogeneao Tree of Life with a multidirectional temporal direction (see Figure 4)

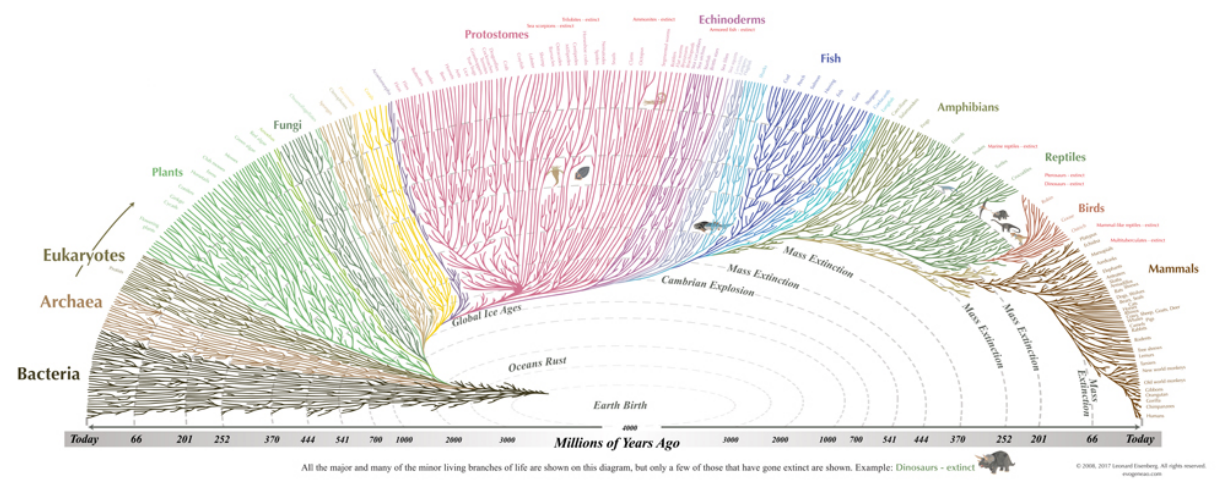

Figure 4. The Evogeneao Tree of Life. Copyright Leonard Eisenberg, 2008, 2017 https://www.evogeneao.com/

4. Digital and interactive representations that are dynamic with a predetermined narrative and limited interactivity (e.g. video animations), for example the animation of hominin evolution used in paper I available at 
http://liu.diva-

portal.org/smash/record.jsf?pid=diva2\%3A1267911\&dswid=1644

5. Digital and interactive representations that are dynamic without a predetermined narrative, and driven by user interactivity. An example of this is the visualization used in paper II the DeepTree exhibit which is available at

https://www.youtube.com/watch?v=dpogiK26el8.

\subsubsection{Phylogenetic trees}

Despite the enormous biological diversity on earth, the notion of common decent is firmly established in biology. A visual representation that has often been used to depict how all organisms are related is the Tree of Life, which communicates both the unity and the diversity of life (Gontier, 2011). The use of tree diagrams to depict natural or divine order of the world can be traced back to ancient Greece (Gontier, 2011). Trees preceding the theory of evolution were often based on affiliation, a term which refers to natural group similarities (Morrison, 2014). Accompanying tree diagrams, networks have been extensively used as well to visualize the affiliation of biological diversity (Morrison, 2014). In the early tree diagrams, time was not a relevant aspect since the affiliation organisms was perceived as due to a divine order or due simply to similarities (Gontier, 2011). Thus, these diagrams usually lack temporal information. Charles Darwin's famous illustration in "The Origin of Species" (1859) had an identical iconography to many of the preceding illustrations based on affiliation (Figure 5), but the underlying rationale was very different, since it was based on genealogy and thus introduced time as a necessary aspect of the schema. The Tree of Life metaphor was in fact one of Darwin's most influential metaphors, even though he himself never called his diagram a "tree" (Gontier, 2011). 


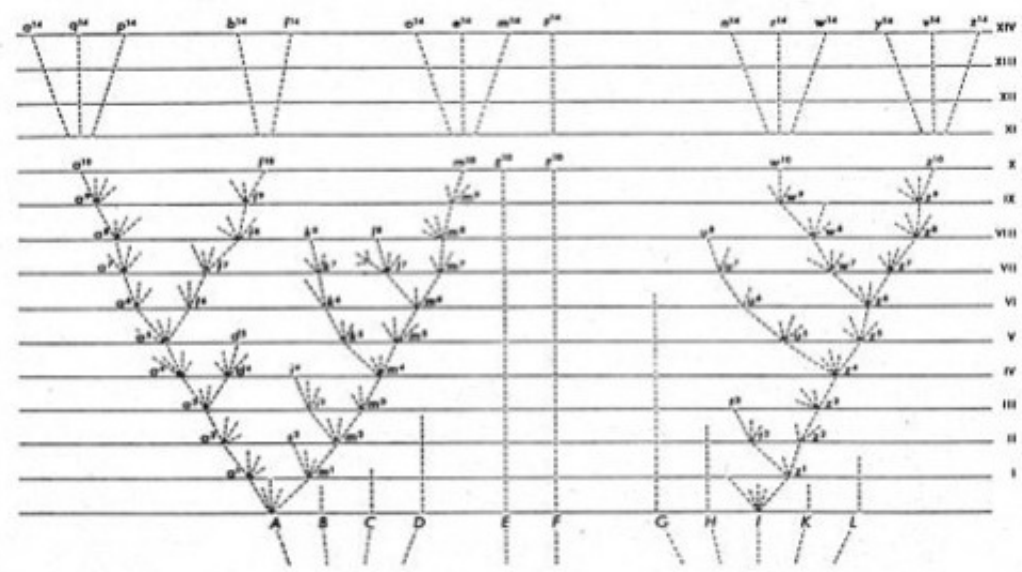

Figure 5. The Tree of life, Darwin (1859). Image source https://commons.wikimedia.org/wiki/File:Darwin\%27s_tree_of_lif e.jpg? uselang $=s v$

A modern and frequent method used to visually represent evolutionary history is by means of phylogenetic trees. As the name implies, evolutionary relationships among organisms are visualized as a tree to indicate that organisms share common ancestors, in a way similar to how branches in a tree share common ancestry with other branches and ultimately a common root. Phylogenetic trees with similar iconography can communicate different meanings, for example in diagrams called a cladogram the temporal dimension is totally absent (see Figure 6A). The diagram only comprises information about the number of shared characteristics and relationships. In other types of phylogenetic diagrams additional information can add meaning to the branch length, for example amount of changes (phylograms, see Figure 6B) or time (chronograms see Figure 6C).
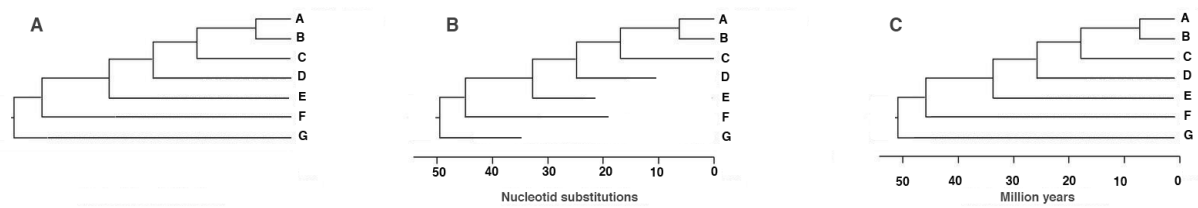

Figure 6 a) cladogram b) phylogram c) chronogram

However, there have been, and still are alternative ways to visualize relatedness, primarily as networks. Networks actually preceded evolutionary trees as illustrations of classification, because biological rela- 
tionships are clearly complex, and networks can illustrate more complexity than can a tree (Morrison, 2014). A tree is thus a visual simplification of a network, leaving out some of the information - the tree metaphor excludes such important biological phenomenon as lateral gene transfer (i.e transmission of DNA other than the "vertical" transmission from parent to offspring) and hybridization.

Much research has been devoted to how users understand and misunderstand phylogenetic trees in general (Baum, Smith, \& Donovan, 2005; Catley \& Novick, 2008; MacDonald \& Wiley, 2012), and a framework or representational competence regarding tree thinking has been developed by Halverson and Friedrichsen (2013). Stephens (2012) addresses the conceptual limitations of the visual metaphor of evolution as a tree, and discusses new ways of visualizing evolution by means of new digital technologies. Nevertheless, only a minor part of the research on phylogenetic trees has been devoted to perception and comprehension of temporal aspects.

\subsubsection{How students understand time in dynamic, spatio- temporal visualizations and phylogenetic trees}

In this thesis, two specific visualizations that incorporate evolutionary time are investigated: timelines and phylogenetic diagrams. Timelines communicate temporal information explicitly whereas phylogenetic diagrams usually communicate time implicitly (exceptions are cladograms which lack temporal information, and chronograms which explicitly express time).

In most phylogenies it is possible to deduce a temporal directionality, but several orientations are possible depending on the design of the phylogeny. The direction is always from the root towards the terminal nodes. In most phylogenetic diagrams the temporal information mainly concerns relative order of occurrences along the different lineages, with the only absolute timestamps being the contemporary species at the tips.

Modern phylogenetic trees can also be arranged in different ways and styles, e.g. having horizontal and vertical lines or diagonal lines, oriented vertically or horizontally see (Figure 7). 


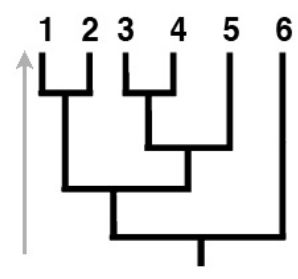

A

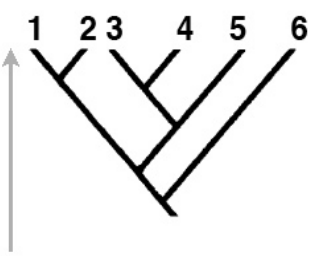

B

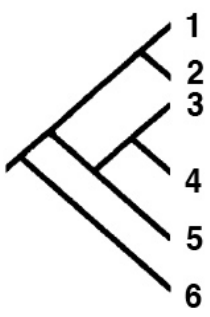

C

Figure 7. Vertical and horizontal temporal directionality in different types of phylogenies. The arrows indicate the temporal directionality and numbers represent species (images based on Gregory, 2008)

In studies performed by Gregory (2008) and Meir et al. (2007), some misconceptions related to time were found, primarily backwards time axes (e.g. misinterpreting the time axis as horizontal rather than vertical) and different lineage ages for modern species (i.e. the view that the time separating contemporary species from a common ancestor is different).

Much research has been conducted regarding learning from different types of timelines (e.g. Boyd-Davis, 2012; Foreman et al., 2008; Korallo et al., 2012; Vít \& Bláha, 2012). In some of the studies, comparisons between timelines on paper/textual displays and virtual timelines have been made (e.g. Foreman et al., 2008; Korallo et al., 2012), which indicates that virtual timelines can be used with success but the results are not entirely coherent. Boyd-Davis (2012) concludes that interactivity enables the learners to control the information, provided that the design is appropriately formed.

Student-generated timelines have been investigated by Cheek (2012), Clary, Brzuszek, and Wandersee (2009), Libarkin, Kurdziel, and Anderson (2007) and Truscott et al. (2006). Clary, Brzuszek, and Wandersee (2009) claim that subject content knowledge is crucial. Results from Libarkin, Kurdziel, and Anderson (2007) show that knowledge concerning differences in temporal scale between events in deep time is poor, whereas comprehension of relative order is better.

Visualizations that include both temporally and spatially variable data are called spatio-temporal visualizations. Monmonier (1990) has distinguished between two alternative ways to design spatio-temporal visualizations, either (i) as highly interactive systems where the user is enabled to navigate and control the temporal aspect, for example by 
using the same technique as spatial zooming (Lee, Devillers, \& Hoeber, 2014), or (ii) as animation graphics where the sequence of events are predetermined and the degree of interactivity is lower. These two ways to design visualizations apply to the two studies performed in this thesis. The study in paper I serves as an example of animation graphics and the study in paper II is an example of a highly interactive system.

In the case of animation graphics, the visualization has to contain complementary temporal and spatial scales. These animations are equipped with animated temporal legends to express temporal information. The representation of time in this kind of legend can be of different types: timelines, time wheels or based on text/numbers.

Vít and Bláha (2012) studied different types of virtual timelines, and found that timelines with units of varying length and a movable slide bar moving at a constant speed was less user friendly than timelines with units of consistent length.
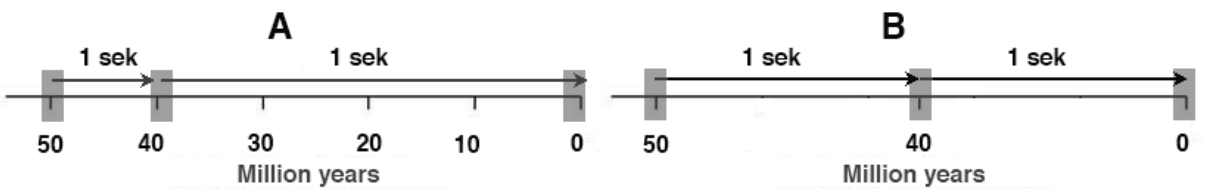

Figure 8. Two ways to alter the animated time rate in an animated timeline with a moving cursor. The cursor (gray rectangle) moves with a variable pace, thus covering different distances along the timeline during corresponding time intervals $(A)$. The cursor moves with a constant rate along the timeline but the units on the timeline are not of equal length (B). These two variant depict the same temporal lapse with a shift in time rate.

This is in line with Lee, et al. (2011), who caution against the use of alterations in time rate by changing the animated temporal "flow" which can be accomplished either by variations in animated time rate or by using timelines with units of varying length (see Figure 8). In animation graphics a particular problem is that two animated objects (i.e. the animation and the animated temporal legend) are displayed concurrently, which can cause cognitive load (Kalyuga, Chandler, \& Sweller, 1999). Even in cases when information in only one of the concurrently displayed animations is necessary, the split attention effect has been shown (Peterson, 1999). 


\subsection{Theoretical Lenses for Considering Students' Interpretation of Evolutionary Time}

\subsubsection{Threshold concepts in science learning}

Much research has been devoted to conceptual change theory (Posner et al., 1982), which has incorporated Piaget's elements of assimilation and accommodation. Assimilation refers to incorporating and adjusting new concepts to fit in and complement an individual's cognitive structure, and accommodation refers to how that new concepts alter existing knowledge structures (Tibell \& Harms, 2017). Building on this tradition, a theoretical framework that rapidly gained interest from many different subject areas emanated from the work of Erik Meyer and Ray Land (Meyer \& Land, 2005). This framework originated from a UK national research project related to characteristics of successful teaching and learning in undergraduate education (Cousin, 2006). It focused on certain concepts called "threshold concepts". These concepts usually have a more underlying, general and abstract nature.

Threshold concepts are characterized by certain features, the most important in this context being that they are:

- Transformative, in that they involve an ontological and conceptual shift:

- Irreversible, i.e. they are unlikely to be forgotten;

- Integrative, in that they disclose new relations, thereby making it possible for the learner to make new connections; and

- Potentially troublesome, since they might oppose "common sense" or intuitive understanding (Cousin, 2006).

Rowbottom (2007) has criticized the theoretical underpinnings of threshold concepts, and pointed out two problems for empirical research based on this framework. First, he asks how is it can be possible to test for concepts and not abilities? Second, how can it be conceivable to tell if there are multiple conceptual routes to the same ability? Despite these problems, the notion of threshold concepts still receives pronounced interest from researchers.

\subsubsection{Time metaphors and embodied learning}

An approach to understanding the basis for abstract thought is through the theoretical framework of embodied cognition. In this framework, metaphors play a vital role in understanding the world, primarily by 
connecting abstract (i.e. non-physical) concepts with bodily experiences (Lakoff, 1999, 2012; Lakoff \& Johnson, 1980).

Wilson (2002) argues that several of the claims made by proponents of embodied cognition should be estimated separately and evaluated on their own merits. Here, I wish to outline three of these claims that are especially relevant to this thesis. The first claim is that cognition is situated (i.e. that cognitive processes occur in real-world contexts, which therefore implicates both perception and action). A second claim is that we off-load cognitive work onto the environment during problem solving. That is, due to limitations of human information-processing, we use external representations to "store" information that we can access and manipulate when we demand it, thus, lowering the load demands of the task. A third claim is that the environment is part of the cognitive system. That is to say, the flow of information between the internal mind and the external world is so interconnected that it is difficult to focus only on the features of the internal world (i.e. the mind) in considering learning.

The most common metaphor for time is mapping time to space, i.e. temporal relations are expressed as corresponding spatial relations (e.g. durations are mapped as distances). In fact, this way of mapping time to space may even be the basis for our way of thinking about time (Boroditsky, 2000). Lakoff and Johnson (1999) mention two variants of the spatial metaphor for time: the time orientation metaphor and the moving observer metaphor. In the time orientation metaphor, present time is the location where the observer is located facing the future, with the past behind. In the moving observer metaphor, the observer is moving towards the future with periods of time conceptualized as distances along the way. Visualizations with animated timelines, such as the representation of time in paper I, mirror the moving observer metaphor, with the observer corresponding to the moving cursor along the timeline.

The same kind of visual metaphor is also expressed in the type of evolutionary diagrams called the Tree of Life, such as the representation investigated in paper II. The root of the tree is the time of the origin of life and contemporary species are found at the tips of the branches. Hence, following any branch from the origin of life towards a branch tip with a contemporary species implies a movement in time (Gregory, 2008). In the application used in paper II this is further reinforced by the zooming being featured much as a journey along a road. 


\subsubsection{Multimodal learning and cognitive load in learn- ing with visualizations}

A large volume of research suggests that an essential aspect to consider in learning with dynamic visualizations is cognitive load (Baddeley, 2003; Moreno \& Mayer, 2007; Paas, Renkl, \& Sweller, 2003). Mayer and Moreno (2003) provided nine ways to reduce cognitive load in multimedia learning. These load reducing principles are based on three assumptions: first, the dual channel assumption (Baddeley, 2003; Paivio, 1990), which states that humans verbal and visual information is processed in separate channels in humans; second, the limited capacity assumption, which claims that each channel has a limited processing capacity; and third, the active processing assumption, which asserts that meaningful learning requires considerable cognitive processing in both channels (Wittrock, 1989).

An effect that Kalyuga, Chandler and Sweller (1999) call the splitattention effect arises from situations where the user cannot simultaneously access two types of information shown in parallel; for example, in the case when a timeline is displayed at the bottom of the display screen and an animation shown above (Baddeley, 2003; Paivio, 1990; Peterson, 1999). The split attention effect has been shown to affect users even when it is unnecessary to use both types of information (Peterson, 1999).

\subsubsection{The role of visualization design on learning}

Visualizations can be a key to successful education provided that they are well designed, and used in educational circumstances that are well suited for the desired outcomes (Phillips, Norris, \& Macnab, 2010).

The two studies included in this thesis are concerned with very different visualizations. In paper I, a more conventional type of representation for time is used - the timeline. In paper II, DeepTree, time is expressed at 200 nodes where common ancestors give rise to two or more lineages of descendants (Block et al., 2012), but it can also be interpreted in a novel and quite different manner - by zooming, which is open to different interpretations to a large degree. Since phylogenetic trees are designed primarily to communicate relationships, it is hardly surprisingly that time is not the prime focus; but one of the goals with the DeepTree is to include time as well (Block et al., 2012). Whereas timelines are relatively well researched (e.g. Boyd-Davis, 2012; Foreman, 2008; Korallo et al., 2012), zooming features as a way to communicate very long time periods are not. 
A particular area that provides relevant information regarding spatio-temporal visualizations, like the one used in paper I, is the use of Geographical Information Systems (GIS). Research in GIS has indicated that the influence of various time representations (a timeline, a time wheel, and a text-based legend) is of minor importance to users (Edsall et al., 1997; Midtbø, Clarke, \& Fabrikant, 2007). Relevant for this thesis is also the research performed by Vít and Bláha (2012), which showed that time represented as a temporal axis, with time units of consistent length and a movable cursor indicating the rate of time, proved to be most user-friendly in comparison with a representation with units of varying length and an animated cursor moving at a constant speed.

In the design and use of animated timelines, designers, teachers and students are faced with conflicting issues if the sequence events of events are unevenly distributed, which is often the case since the details in history become more and more scarce when moving from the present time towards the distant past (Boyd-Davis, 2013a). In an educational context, the importance of narrative can be vital, which would imply the use of variable rate of time rate under these circumstances. However, research contradicting this approach suggests cautious use of alterations in time rates, since it might accentuate the tendency to underestimate the duration of long time periods and overestimate the duration of short periods of time (Lee et al., 2011). This would reinforce temporal misunderstandings.

In paper II, a different approach to communicate evolutionary time was investigated, which included zooming. This kind of interface allows users to virtually "travel" in any dimension be it time or space. Much less research has been performed in this area.

Other important aspects to consider in the design and choice of dynamic visualization of time is the cognitive load demands discussed in the preceding section. 


\section{Aims and Research Questions}

The overarching aim of this thesis is to empirically investigate students' interpretation of dynamic visualizations of evolutionary time. Both studies included in the thesis are descriptive and explorative, and concerned with aspects of how visual design affects students' comprehension of evolutionary time.

The research questions investigated in paper I relate to a spatiotemporal animation specifically produced for the research project, depicting the evolution of the hominin lineage during the last 7 million years. The animation was supplied with one of four alternative versions of time representations, which differed in whether the time rate was constant or variable and whether one timeline or three emerging timelines were used. Thus, it was possible to present four possible combinations of these two factors.

The research questions investigated in paper I were as follows:

How do the different versions of time representation affect students' ability to

1. find events at specific times?

2. comprehend the relative order of events?

3. estimate the duration of a time interval?

4. compare different temporal durations?

5. comprehend the concurrency of events?

Each of the time representations mentioned above have been analyzed regarding students' comprehension of these temporal aspects.

The research questions investigated in paper II related to a digital interactive tabletop visualization of the Tree of Life called DeepTree, which was part of a project called "Life on Earth", tested and evaluated at the Harvard Museum of Natural History in 2011-2012 (Block et al., 2012). Since the zooming feature in this application was of particular interest in paper II, the investigated part of the tabletop was restricted to the main tree visualization in DeepTree, where this feature is prominent.

The specific research questions posed in relation to the application were:

1. How do students interact with DeepTree in the exploration of evolutionary time?

2. How does zooming influence students' interpretation of evolutionary time? 
3. What potential misinterpretations about evolutionary time are associated with students' interaction with DeepTree?

The research questions in paper I were also investigated in paper II, since they constitute implicit aspects of research question 2 and 3 . 


\section{Methods}

\subsection{Brief Description of the Visualizations Investigated in the Research}

The visualizations in the two included papers were chosen on the basis that they illustrate different ways of communicating evolutionary time, in terms of content, interactivity and form (see Table 2). In the following text the visualizations are described more in detail.

Table 2. A comparison of the two visualizations used in the thesis

\begin{tabular}{|c|c|c|}
\hline & Paper I & Paper II \\
\hline Time in relation to & Geographical distribution & Phylogeny \\
\hline Time span & 7 million years & 3500 million years \\
\hline Time visualized as & Animated timelines & Explicit internal nodes \\
\hline Production & $\begin{array}{l}\text { Specifically designed for the } \\
\text { study by the author of this } \\
\text { thesis }\end{array}$ & $\begin{array}{l}\text { Produced in the project } \\
\text { "Life on Earth (Block } \\
\text { et al., 2012) }\end{array}$ \\
\hline $\begin{array}{l}\text { Number of taxa in- } \\
\text { cluded }\end{array}$ & 7 & 70000 \\
\hline $\begin{array}{l}\text { Narrative/sequence } \\
\text { of events }\end{array}$ & Predetermined & $\begin{array}{l}\text { Determined by the } \\
\text { user }\end{array}$ \\
\hline Interface & $\begin{array}{l}\text { A video display with the } \\
\text { possibility to play and } \\
\text { pause the animation }\end{array}$ & $\begin{array}{l}\text { Touch-based interac- } \\
\text { tive surface }\end{array}$ \\
\hline $\begin{array}{l}\text { Degree of inter- } \\
\text { activity }\end{array}$ & $\begin{array}{l}\text { Stop and play the anima- } \\
\text { tion }\end{array}$ & $\begin{array}{l}\text { Driven by active inter- } \\
\text { actions through finger } \\
\text { gestures }\end{array}$ \\
\hline
\end{tabular}

\subsubsection{The animation used in paper $I$}

The development of the animation used in paper I was the result of a survey of existing spatio-temporal animations involving evolutionary time, found at Museums and online. The representation of time is in one sense traditional - based on timelines, a way to visualize time that has been used for at least 250 years (Boyd-Davis, 2012), but in this case also complemented with new animated features. The animations can be found at:

http://liu.diva-

portal.org/smash/record.jsf?pid=diva2\%3A1267911\&dswid $=44$

The reasons for choosing evolutionary time in relation to the dynamic distribution of taxa were that: a) the combination of information containing large scales both in space and time presents an important but less commonly used perspective on evolution, and b) this kind of 
information benefits from new technologies capable of presenting dynamic phenomenon.

We chose the evolution of the hominin evolution since it has proven to be highly motivating for students (Besterman \& Baggott La Velle, 2007), and the relevant time span takes an intermediate position in terms of evolutionary time - far from human experience but still only constituting an insignificant fraction of the full evolutionary history of all organisms.

The animations used in paper I were created by myself during 2015, with new findings in paleoanthropology that have modified details in the picture of hominin evolution. To avoid information overload, some of the species have been omitted from the animations, for example $H$. floresiensis (Brown et al., 2004) and H.naledi, as well as some of the species included in the genus Paranthropus.

A combination of the software programs Adobe Photoshop and Adobe After Effects was used in the construction of the animations. A static, small-scale map, covering Europe, Asia, Australia and Africa, acts as a geographical background. The Americas were excluded in order to avoid reducing the geographic scale. Moreover, the dispersal of $H$. sapiens to America occurred late in the history of hominins, with no additional species at that time.

Before finalizing the animation used in paper I, a pilot study was conducted with 12 students during the spring of 2016, with a prototype animation that we then refined. Four interviews with users were also conducted, to investigate how the prototype was experienced. Results from the pilot were considered when the final version of the animation was created.

The finalized visualization is designed as a map superimposed with animated areas representing the dynamic dispersal and distribution of a chosen sample of taxa, i.e. different species, or groups of species in hominin evolution during the last 7 million years (Wood, 2010). The choice of included species and groups of species were based on what was considered to be a suitable number of well-established taxa to be presented in a dynamic spatio-temporal animation, considering the cognitive load and amount of information presented. The animation is 3 minutes and 30 seconds long. The rationale for this particular length is to provide an animation long enough to display relatively short time intervals in evolutionary terms (e.g. the existence of $H$. sapiens) in a reasonable "temporal resolution" (i.e. not happening too fast), while at the same time not prolonging the periods with few events more than necessary, to enable users to compare very long and very short time intervals. 
Of pivotal interest in paper I is the different representations of time. How these differences affect the way relevant temporal aspects are comprehended is of central interest in the study. A combination of two factors were investigated: the number of emerging timelines with different scales, and the animated rate of time, either constant or with decreasing rate as the animation reached the present time.

The combination of these two factors yields four versions of representations of time:

Animation A One timeline, and a constant time rate Animation B One timeline, and a time rate that decreases as the animation approaches the present time Animation C three emerging timelines of increasing scales that become visible as the animation approaches the present time, and a constant time rate

Animation D three emerging timelines of increasing scales that become visible, and a time rate that decreases as the animation approaches the present time

The current time in the animation is indicated by an animated cursor moving along the timelines. The level of interactivity was limited, but at all times the user was able to play, stop and replay the animation. The actual visualizations can be found at:

http://urn.kb.se/resolve?urn=urn:nbn:se:liu:diva-153235

\subsubsection{The DeepTree application}

In contrast to the animation of the hominin evolution, the visualization in paper II, DeepTree, is ready-made. The design and development of the application has been described by Block et al. (2012). It provides a new, highly interactive and novel way of communicating evolutionary time. This application is presented on the internet, for example at: https://www.youtube.com/watch?v=dpogiK26el8.

Contrary to the visualization of the hominin evolution, DeepTree encompasses the full evolutionary history of life on earth, which is approximately 500 times longer than the hominin timespan. It was produced as an interactive tabletop exhibit intended for use in museums. Approximately 70 ooo species are represented in DeepTree, and among these 8000 are represented with images (Block et al., 2012). A clearly stated aim was to include evolutionary time in the application. Thus, 200 internal nodes in DeepTree are labeled with their estimated time. In paper II we have specifically investigated temporal aspects of DeepTree. 
This kind of touch-sensitive technology has already entered the domain of education, e.g. in the form of interactive whiteboards, and small interactive devices with touch-sensitive interfaces of different kinds. DeepTree is a multi-touch application that can be operated by single users as well, and constitutes a modern version of the Tree of Life. The ability to zoom is a striking feature to most users.

Zooming is achieved by moving a finger down the screen, which causes the tree to move downward at the same time as more details in the canopy becomes visible, causing a "zooming in" effect. Similarly, moving a finger upward on the tabletop causes the tree to move up, revealing new nodes below, while details at the top vanish, causing a "zooming out" effect.

\subsection{Study Context and Data Collection}

In this section the study context, data collection, data analysis, and aspects of reliability and validity are considered. An overview with a comparison of the two studies is presented in Table 3.

Table 3. Participants, setting, data collection and analysis in the two included studies

\begin{tabular}{|c|c|c|}
\hline & Paper I & Paper II \\
\hline Participants & $\begin{array}{l}\text { University students, prima- } \\
\text { ry teachers, college year }\end{array}$ & $\begin{array}{l}\text { Upper secondary students, } \\
\text { social science program }\end{array}$ \\
\hline $\begin{array}{l}\text { Number of par- } \\
\text { ticipants }\end{array}$ & 144 & 10 \\
\hline Setting & Real world & Clinical \\
\hline Data collection & $\begin{array}{l}\text { Questionnaire with } \\
10 \text { questions, } \\
\text { 2/Research question }\end{array}$ & $\begin{array}{l}\text { Semi structured interview, } \\
\text { video of interactions }\end{array}$ \\
\hline "Type of data" & Task based & $\begin{array}{l}\text { "Think aloud" guided by } \\
\text { questions, tasks }\end{array}$ \\
\hline Data analysis & $\begin{array}{l}\text { Primarily deductive } \\
\text { correct-incorrect answers }\end{array}$ & $\begin{array}{l}\text { Inductive, deductive, themes, } \\
\text { zooming frequency and time }\end{array}$ \\
\hline
\end{tabular}




\subsubsection{Study context}

The study in paper I concerning visualization of the hominin evolution involved 144 university students. The data were collected in four rounds during a period of 15 months. In three of the rounds the participants were recruited from a teacher education programme targeting the age group 6-9 years. During the second round, students enrolled in "The Natural Sciences Competence Educational Course", corresponding to upper secondary level were recruited. The gender distribution was biased towards females (73\%) among the participants.

In each round the students were distributed among two or three of the animations, so that specific animations were not attributed to specific rounds or groups of students. The intervention was conducted in a computer lab in which each student worked individually, with the information presented on a computer screen. The average age of the participants varied between 22.6 and 24.5 years in the different rounds.

Before conducting the intervention, a questionnaire was distributed with the purpose to gain knowledge about the participants' general background (e.g. age, gender, former education, interest in science), their pre-knowledge about hominin evolution, and their abilities to solve a basic arithmetic task, reading a timeline and comparing the size of two rectangles. This was done in order to establish the "baseline" and potential influence of background, education and abilities that could influence the results. Furthermore, after the intervention was performed we delivered three questions regarding how hard the students found the task they had been given, how clear the language was, and how difficult they found the depicted scenario to be.

In contrast the study in paper II involved only ten participants recruited from an upper secondary school. The students were enrolled in a social science programme, and the average age was 17.3 years. In this study the gender distribution among the participants was also biased towards females (80\%). The actual study was performed in a computer lab. Each student worked individually in front of an interactive tabletop, with the interviewer located beside the tabletop (see Figure 9). 

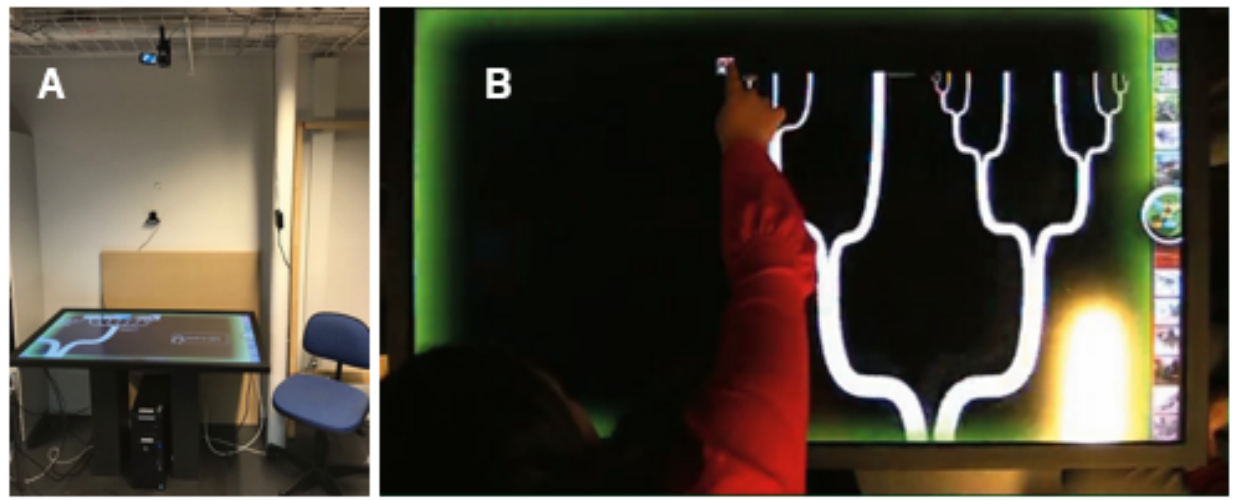

Figure 9. A) The study context in paper II B) The perspective caught by the video camera

\subsubsection{Data collection}

Preceding the studies, all participants were informed about the conditions of the current study, and were asked to sign a form of consent. Then, they all filled in a preliminary questionnaire concerning their background (age, gender, educational background, interest in science/biology) and pre-knowledge about the relevant aspects of evolution in each study, and were finally tested for skill/abilities that might affect the results.

The data collected in paper I were based on a questionnaire (see Table 4), which the student answered digitally while engaged with the animation. The format of the questions where either true or false, multiple choice, or open answers. The data in paper II were collected as video-recordings during a clinical semi-structured interview (see Table 5).

The two authors developed the questionnaire used in paper I to ensure construct validity and trustworthiness, in a process that also involved a pilot study with 12 participants and four interviews with individual students (Robson, 2011).

How the research questions are linked to the questions in the questionnaire in paper I can be seen in Table 4. 


\section{Item}

1. When did the group with Australopithecus species appear?

2. When did the last ice age begin?

3. What different species of Hominins existed between the penultimate and the last ice age?

4. Did Homo heidelbergensis exist at the same time as Homo sapiens?

5. Did Homo habilis exist before the appearance of Homo erectus?

6. Did Homo erectus exist before the appearance of Australopithecus?

7. How long did the group of Sahelanthropus, Orrorin and Ardipithecus exist?

8. How long was the penultimate ice age?

9. Compare the time Homo neanderthalensis existed with the time Homo habilis existed.

10. How long did the group of genus Sahelanthropus, Orrorin and Ardipithecus exist compared to Homo sapiens?

\section{Related to question regarding}

Finding events at specific times

Finding events at specific times

Comprehending concurrency

Comprehending concurrency

Comprehending relative order

Comprehending relative order

Estimation of duration

Estimation of duration

Comparisons of durations

Comparisons of durations

The data collection in paper I was performed in a computer classroom where each student worked individually. Since we wanted to understand how the visualization was perceived during the time the students were actively engaged in working with the animation, they were faced with two open windows: one displaying a questionnaire with questions related to the animation, and the other displaying the actual animation. Thus, they were able to access both the animation and the questionnaire at the same time.

We also performed screen recordings of the actions performed, to ensure that as much information as possible was collected. The study also included two additional parts. One of these tasks was to re-present the scenario they had experienced in an alternative graphical way; and the other part involved mathematical problems to solve in relation to 
the depicted scenario. Results from the screen recordings and the complementary parts of the investigation will hopefully be analysed in later studies

The data collecting procedure in paper II was done in the form of clinical semi-structured interviews with individual students one at a time. The protocol for the semi-structured interviews (see Table 5) was developed by the three authors in an iterative manner, including two pilot studies. The participants were actively engaged in interactions with the application, guided primarily by the questions from the interviewer. The sessions were video recorded with a camera located straight above the tabletop, so that the actions on the interface were visible (see Figure 9).

At the onset of the interview the students were told that this was a representation that shows evolution, and that the investigation concerns how the visualization works and how it is understood by users.

Table 5. The protocol for the semi-structured interview and the aspects the different questions addressed

\begin{tabular}{|c|c|c|c|}
\hline & Interview Question & $\begin{array}{l}\text { Rational for posing the inter- } \\
\text { view question (e.g. how the } \\
\text { interview probe relates to the } \\
\text { research questions) }\end{array}$ & $\begin{array}{l}\text { Conceptual and } \\
\text { reasoning aspect } \\
\text { of interest }\end{array}$ \\
\hline 1 & $\begin{array}{l}\text { The pupils should be en- } \\
\text { couraged to investigate } \\
\text { zooming and panning. } \\
\text { What does it mean to pull } \\
\text { down (Pull down to zoom } \\
\text { in)? } \\
\text { What does it mean to pull } \\
\text { up (Push up to zoom out). } \\
\text { What happens when you } \\
\text { pull down and sideways } \\
\text { (drag two pan). } \\
\text { Supplementary questions. } \\
\text { What happens? - How? } \\
\text { When is now }\end{array}$ & $\begin{array}{l}\text { The purpose of the question } \\
\text { is to understand how the } \\
\text { student experiences the } \\
\text { movement the different ges- } \\
\text { tures results in. How do you } \\
\text { perceive that time is repre- } \\
\text { sented in the animation? }\end{array}$ & $\begin{array}{l}\text { Zooming \& } \\
\text { Time }\end{array}$ \\
\hline 2 & $\begin{array}{l}\text { We begin with examining } \\
\text { the function of the tree by } \\
\text { zooming starting from the } \\
\text { origin of life (the student } \\
\text { can do it him/herself) } \\
\text { towards two species: First } \\
\text { Metanopyrus kandleri - a } \\
\text { type of methane bacteria } \\
\text { and then Homo sapiens. A } \\
\text { question is concerning }\end{array}$ & $\begin{array}{l}\text { The zoom time represents } \\
\text { the same real time span but it } \\
\text { is approx. 10 times shorter } \\
\text { for Metanopyrus kandleri. } \\
\text { This reveals if the student } \\
\text { understand that the timeline } \\
\text { is not "equal" - that there are } \\
\text { different timelines for differ- } \\
\text { ent branches - that it is not } \\
\text { the same. }\end{array}$ & $\begin{array}{l}\text { Time } \\
\text { - Estimating a } \\
\text { duration } \\
\text { - Comparing } \\
\text { time intervals }\end{array}$ \\
\hline
\end{tabular}


what the student has just witnessed; compare how long time it took for these organisms (Homo sapiens vs Metanopyrus kandleri) to develop?

$3 \quad$ What does the branching represent?

4 Pairwise compare and write down:

How long ago did the most recent common ancestor to?

- banana and human live? (recent joint ancestors lived 1, 4 billion years ago) - yeast and man live? (recent joint ancestors lived for 1049 million years)

- E.coli and human live? (recent joint ancestors lived 3.5 billion years ago) - Tyrannosaurus and human live? (recent common ancestors lived 302 million years ago)

Then transfer the information to a timeline. Did you expect it or not? Why?

5 The pupils are then given the task of comparing two pairs of species First tyrannosaurus and velicoraptor then velicoraptor and house sparrow. Which species are more closely related? Reflections.

6 Zoom in to a species of your choice. Zoom out
First to investigate whether the concept of most recent common ancestors is relevant second to be able to develop it if it is not the case. This is to give everyone the same background in the forthcoming questions

Provide students with a paper containing a linear timeline to fill in the different times.

The purpose of the question is to investigate whether the student understands the tree metaphor because the result is contra-intuitive (should give rise to a certain cognitive conflict)?

\section{Relatedness}

Time

- Finding events at specific times - Relative order,

\section{Relatedness}

Relatedness 
slowly and specify what are the closest relatives and the groups and times that appear.)

7 Zoom in to the Homo sapiens. Then zoom out bit by bit and indicate how long ago our most recent common ancestors with

a) Chimpanzees lived

b) Gorilla lived

c) Orangutan lived

8 Compare when the most recent common ancestor of orangutan and man lived with when the most recent common ancestor of human and chimpanzees lived.

9 Compare when the most recent common ancestor to tomato and potato lived (2 million years), respectively tomato and silkworm (118 million years)

10 Where in the tree is a billion years ago?

11 If there is an opportunity to investigate "FlowTree" ask the following questions

1. What are the dots for? Follow-up question: What is the colour change for? 2. What is each line for? 3. How many generations are needed for a new species to be formed (discussion question without a clean answer)

12 Additional questions that may arise at potentially appropriate times or posed at the close of the session
The purpose of this question is to see if time i.e. order (time vertically) is perceived correctly. How easy it is to find explicit dates.

The purpose of this question is to investigate the perception of simultaneity, to what extent the inconsistent visualization of the time axis of the tree gives rise to misconceptions (time horizontally).

Shows if the student understands that the tree is inconsistent temporally
Time

-Finding events at specific times - Relative order

\section{Relatedness \& Time}

- Finding events at specific times

- Relative order

Time

- Finding events at specific times

- Relative order

- Concurrency

\section{Time}

- Finding events at specific times

- Concurrency
Time

- Finding events at specific times 
- Where is the tree now?

- Where are living and

extinct species in the tree?

- The tree shows different

aspects of life - what as-

pects do you think of

when you see the tree?

(unit and diversity)

- What was the most strik-

ing / instructive of the

application

\subsection{Analysis}

Both studies included in the thesis are descriptive and exploratory and preceded by pilot studies which guided the final research design. The data collected from the two included studies were of different character and were analysed in different ways.

\subsubsection{Categorization of response in paper $I$}

In paper I the students were asked to answer questions. Since these questions were of various formats (e.g. open ended, multiple choice) we had to standardize the answers to be able to compare the results. Thus, the results were categorized as either correct or incorrect. The multiplechoice questions were already in a format that resulted in either a correct or incorrect answer, but questions concerning finding events in time and estimating the duration of a time interval had to be categorized. After considering what boundary could be most valid, we agreed that a $10 \%$ deviation from the correct value would still be considered as correct, since that hardly would impact learners' understanding of evolutionary time. One question with a unique format concerned how many concurrent hominin species coexisted between the penultimate and last ice-age. If more than one species was mentioned the answer was considered as correct (i.e. a certain degree of ability to comprehend concurrent events).

The results from each group working with a specific animation were then aggregated, and a mean score for each group and question was calculated, to enable comparisons between the groups. 


\subsubsection{Emergent themes from the interviews reported in paper II}

We analysed the transcripts from the semi-structured interview using thematic content analysis, which is a generic method not necessarily tied to any particular theoretical framework, and possible to combine with predetermined codes (Robson, 2011).

The interview protocol was derived from prior research, and based on experiences from the preceding pilots. It included predetermined codes to target crucial concepts, but additional codes that emerged inductively from the data were added during the analysis. This combination of deductive and inductive methods resonates well with Mayring (2000) and Fereday and Muir-Cochrane (2006). The rationale for using this dual approach was to gain as complete and rich information as possible from the data. The predisposed deductive analysis ensured that anticipated themes in the study were explored, while the inductive analysis allowed for unanticipated themes to emerge from the data during the analytic process.

In the deductive analysis of the transcripts and video-recordings, the authors each analyzed two arbitrarily assigned transcripts with regard to the predetermined codes. Hence, six of the transcripts were jointly analyzed, to reach agreement upon refinements of the coding regarding variations and subcategories.

The analytic steps in the inductive analysis of the transcripts and video-recordings were:

1. Three researchers each read two of the transcripts to look for emergent themes that could be used in the coding schema (i.e. for the study relevant and salient utterances or actions)

2. An inductive code schema was developed based on the results from the preceding step

3. The new coding schema was applied to two new transcripts

4. Based on the outcome of the preceding step the coding schema was further modified

5. The coding schema modified in the preceding step was applied to two new transcripts

6. Based on the outcome of the preceding step the coding schema was further modified and finalized

7. All of the transcripts were inductively analysed using the final coding schema 


\subsubsection{Analysis of interactions in paper II}

DeepTree entails rich opportunities to interact, primarily by zooming. We analyzed interactions in relation to zooming in two ways: partly by measuring the amount and intensity of zooming actions, and partly as a qualitative analysis of utterances made about zooming experiences.

Regarding the amount and intensity of zooming actions, we first recorded the intensity of zooming (i.e. how many zooming events the participant performed per minute), and then the fraction of time devoted to zooming during the engagement with the tabletop. Both of these parameters were extracted from the video recordings.

The qualitative analysis of utterances relating to zooming was done in an inductive way using MAXQDA 2018 (VERBI Software, 2017) in the following way:

1. All transcripts were analysed with regard to utterances that made reference to zooming or were related to zooming actions

2. The utterances were coded in two ways - whether the zooming event referred to movements in a temporal space (i.e. as motion in time) or a spatial space (i.e. as motion within the tree metaphor)

3. Utterances that included explicit indications of direction of the zooming movement (most frequently forward/backward, up/down, nearer/further, in/out) where coded in accordance with the attributed direction.

Thus, each utterance about zooming was subcategorized depending on whether, and how, the zooming was expressed in terms of dimension (time or "metaphoric" space) and direction of the movement. This was done independently by two of the authors.

\subsection{Reliability and Validity}

Both of the studies included in this thesis are descriptive and explorative, and neither is quantitative. Thus, issues concerning validity and reliability have to be considered in this context.

In paper I the construct validity (i.e. whether it measures what is intended to be measured) of the items in the test instrument was assured by having two researchers who developed the questions specifically for the study. Furthermore, to ensure that the items were interpreted by the users in the way intended, we performed interviews with four participants in the pilot studies concerning the phrasing of the questions. Moreover, we also made recordings of the events displayed on the screen, which made it possible to revisit any action, including answering the questions. Thus, it was possible to use the screen-recordings as 
a part of a triangulation. Since we did not use a specific theoretical framework in the analysis of the test instrument, some of the main threats to validity were avoided, e.g. errors in interpretation due to imposing an assumed meaning and exclusion of alternative explanations (Robson, 2011).

Paper I was performed in a real world setting (i.e. in a real educational setting), which means that reliability is hard to guarantee, but the internal generalizability (i.e. within the study) is assured since the same animations and the test instrument were used in the same classrooms in the same way, guided and observed by the same researcher. The external generalizability, that is, generalizability beyond the setting studied (Robson, 2011), is lower since the study did not use a random sample of participants.

In paper II a dual approach was used, including both a deductive and an inductive analysis. Based on prior research and results from the preceding pilot studies, a protocol for a semi-structured interview was developed by the three authors together. This ensured the construct validity of the items with predetermined themes.

To ensure the validity and trustworthiness of the inductive analysis in paper II, the three researches developed the coding schema in the iterative manner described above. The inter-rater reliability was assured by two of the authors, who independently coded all of the utterances about the zooming experience, and reached an agreement that resolved any dissimilarities in coding after a discussion. Furthermore, all of the interactions and utterances made by the participants were video-recorded, thus providing a rich complementary source of information that also served as a triangulation (Robson, 2011).

Since the study in paper II was conducted in a clinical setting, the internal generalizability is high due to the controlled milieu, whereas it is hard to claim a high external generalizability, for the same reason.

\subsection{Ethical Considerations}

The research was conducted in accordance with the principle and guidelines provided by the Swedish Research Council (Gustafsson, Hermerén, \& Petersson, 2006). Prior to each of the studies all participants were informed about the purpose of the study, and signed a form of consent (see Appendix I \& II). All of the information was treated anonymously. Moreover, in paper I all of the information was treated in aggregated form. 


\section{Findings}

In paper I a depiction of time based on the traditional western convention (i.e. the passage of time occurs along a timeline in one direction, from left to right) was used, but complemented with additional features afforded by the digital environment. In paper II a very different and much less commonly used approach to visually communicate temporal aspects was used, based on a touch-sensitive interface, with the temporal dimension being less bound to particular cultural conventions (Domenjó, 2010). In fact, it is still uncommon to use a third "depth" dimension to control the temporal dimension in digital environments, but there are examples, such as the Khronos projector (Cassinelli \& Ishikawa, 2005).

First, an account of findings in the separate studies will be presented, followed by a comparison and compilation of findings that are relevant to both papers.

\subsection{Paper I}

The results from paper I show how well the students were able to interpret five different temporal aspects (finding events at specific times, comprehending the relative order of events, estimating the duration of a time interval, comparing different temporal durations and comprehending the concurrency of events) in four alternative representations of time in an animation.

- Of the two factors we investigated, time rate and number of timelines, the most critical factor was the number of timelines. The animations with only one timeline (A and $\mathrm{B}$ ) gave rise to low scores concerning items located near the present time. This was particularly pronounced in the items related to finding events at specific times and estimating a time interval.

- The number of timelines did not, to any notable extent, affect the results concerning the ability to apprehend relative order, and to compare the duration of two time intervals.

- In the case of a constant time rate with several timelines displayed (i.e. animation C), the quick series of events close to the present time impaired the comprehension of concurrent events.

- Regarding the ability to comprehend concurrent events located near the present time, the student groups with a decreasing 
time pace succeeded much better than those with a constant time rate.

- In general, the animation that displayed three timelines and a decreasing rate of time (D) gave rise to the best results, with one notable exception: comparing the duration of two time intervals that spanned parts of the timeline with different scales. In this item, students working with animation D succeeded worst of all groups.

\subsection{Paper II}

In paper II we focused on three aspects of an application called DeepTree: how students interact with the application, how students interpret zooming, and which misinterpretations arise from the interactions with DeepTree. The application elicited a very strong affective reaction among many students. Utterances such as: "Woow!", "Ahh ..! Oops! .. Oh oh oh!", "I think it's cool” were frequent.

Two aspects of interactions were investigated: the frequency of zooming (i.e. the number of zooming events per minute), and the proportion of time spent on zooming while working with DeepTree.

- The students showed considerable variation concerning both frequency and time spent on zooming. Generally, a higher proportion of time spent on zooming accompanied a higher zooming intensity, but several exceptions existed.

- All students except one expressed the experience of zooming as a movement in a temporal space (i.e. in time) and/or in a spatial space (i.e. in the tree, along branches that represent relatedness).

- In two thirds (69\%) of the utterances about zooming the direction of movement was expressed.

- In utterances concerning the direction of movements in time, the vast majority (62\%) were stated in terms of going forward/backward, whereas the predominant (44\%) direction expressed in relation to movements in the tree was nearer/further (i.e. using a proximity metaphor).

- The proximity metaphor was used in three different ways by the students: as closeness within the tree metaphor, that is, closeness in terms of neighborhood $(n=7)$; as close relationships $(n=3)$; and as a closeness to the tree itself, i.e. as if the tree or the user was approaching each other $(n=3)$. 
- Two distinct groups were discerned: students who made many utterances (6 or more) about movements in time, and students who talked less about temporal movements (with 2 or fewer utterances). Hereafter, I will denote the group with many utterances about time $\mathrm{T}$ (abbreviation for temporal) and the group with few utterances about time $\mathrm{S}$ (abbreviation for spatial).

- Group T also made more utterances generally and interacted more than did group $\mathrm{S}$

- The results also reveal several misinterpretations:

a) the assumption that there is an implicit coherent timeline along the $y$-axis of the interface that could be applied to all of the lineages in the tree $(n=4)$,

b) the assumption that zooming time corresponds to real evolutionary time in a consistent way $(n=10)$,

c) the assumption that the branch tips represent present time $(n=4)$, and

d) the assumption that more nodes (i.e. "branching points") along a lineage means longer real time $(n=5)$.

\subsection{Comparison of Findings in Both Papers}

In the following text, the findings with relevance to both papers are described and compared in the light of each other. Of course, the comparisons are imprecise, since the questions and tasks were different and set in different situations, but they do provide a basis for evaluating how the different visualizations communicate the various temporal aspects investigated.

\section{How do the different versions of time representation affect students' ability to find events at specific times?}

Generally, finding events at specific times was not a difficult task in the visualization used in paper I, except for animations with only one timeline near the end of the time where the sequence of events appeared very quickly, which resulted in low results.

Since DeepTree lacks a coherent time axis (as the primary purpose of the tree is not to convey time but relatedness), identifying specific times was much harder and prone to be misinterpreted, except for: those specific times that were explicitly labelled in the tree, contemporary species in the canopy, and the origin of life. This was illustrated by question 8 and 10 in the semi-structured interview (see Table 5). 
How do the different versions of time representation affect students' ability to comprehend the relative order of events?

The results show that comprehending relative order was not difficult for the participants in paper I, independent of where the times were located on the timeline and independent of which animation was used. The same results apply to paper II, in which all of the students who answered question $7(n=5)$ were correct (see Table 5$)$. This result is in line with prior research (e.g. Libarkin, Kurdziel, \& Anderson, 2007).

\section{How do the different versions of time representation affect students' ability to estimate the duration of a time interval?} The ability to estimate the duration of a time interval in paper I appeared to depend much on which visualization was used, as it was more difficult for groups working with animations with only one timeline, especially near the end of the animation, where the sequence of events occurred quickly. In paper II, estimating the duration of time intervals was prone to be misunderstood by all users which was revealed in question 2 (see Table 5), since zooming time was equated with the time interval, which is not correct.

\section{How do the different versions of time representation affect students' ability to compare different temporal durations?}

Making correct comparisons of time intervals in paper I was relatively independent of which animation was used, with one exception: student groups working with an animation featuring several timelines and a decreasing default animated time rate performed worst at comparing events with intervals that spanned parts of the timeline with different scales (contrary to the relatively high score on every other aspect investigated). In paper II, all students $(\mathrm{n}=10)$ were unable to compare time intervals, since zooming time was equated with time interval, which is not correct. This was revealed by results from question 2 in Table 5 .

\section{How do the different versions of time representation affect students' ability to comprehend the concurrency of events?} The most influential factor in paper I affecting the ability to comprehend concurrent events was high cognitive load. This was particularly pronounced in animations where several timelines were displayed simultaneously and the animation speed was relatively high. In paper II the participants faced a different kind of problem in perceiving and comprehending concurrent events: the implicit and incoherent time axis leading from the root to the canopy. This was evident considering the results from question 10 in Table 5, where four of the seven students 
who answered the question misinterpreted the temporal information. Thus, they could not correctly comprehend concurrent events. A summary of these comparisons is presented below.

Table 6. A comparison of how hard it was to understand different temporal aspects in the two visualizations

\begin{tabular}{|c|c|c|}
\hline Students' ability to & Timeline & $\begin{array}{l}\text { DeepTree } \\
\text { (Zooming) }\end{array}$ \\
\hline find events at specific times & $\begin{array}{l}\text { Easy in animations with ex- } \\
\text { panded timelines (C and D) }\end{array}$ & $\begin{array}{l}\text { Difficult } \\
\text { (unless } \\
\text { labelled } \\
\text { in the tree) }\end{array}$ \\
\hline $\begin{array}{l}\text { comprehend the relative order } \\
\text { of events? }\end{array}$ & Easy & Easy \\
\hline $\begin{array}{l}\text { estimate the duration of a time } \\
\text { interval? }\end{array}$ & $\begin{array}{l}\text { Easy in animations with ex- } \\
\text { panded timelines (C and D) }\end{array}$ & Difficult \\
\hline $\begin{array}{l}\text { compare different temporal } \\
\text { durations? }\end{array}$ & $\begin{array}{l}\text { Difficult for all, but most } \\
\text { difficult for animation D }\end{array}$ & Difficult \\
\hline $\begin{array}{l}\text { comprehend the concurrency } \\
\text { of events? }\end{array}$ & $\begin{array}{l}\text { Difficult if many timelines, } \\
\text { but most difficult in C }\end{array}$ & Difficult \\
\hline
\end{tabular}




\section{Discussion and Implications}

Considering, important contemporary environmental and health issues, the need to understand evolution and evolutionary time seems ever so urgent. These are problems with many implications from philosophical (e.g. ethical, aesthetical) to practical (e.g. public health, economical) issues. Furthermore, they highlight different aspects of evolutionary time: loss of biodiversity and climate change should be considered in the light of speciation, and the current climate change should be compared with the rate of former climate changes, i.e. long evolutionary time.

The challenge of understanding evolutionary time is largely due to the different magnitudes of the temporal scales involved. Thus, the thesis research supports the claim that temporal scales constitute a threshold concept in biology (Ross et al., 2010) that should be consciously considered when teaching evolution. Time spans covering millions of years are challenging for learners, since the magnitude of scale is far from human experience and prone to be underestimated (Lee et al., 2011).

Furthermore, this poses a problem when designing representations of evolutionary time, since the temporal distribution of events often tends to be uneven (Vít \& Bláha, 2012) and often there is a need to switch between overview and detail (Boyd-Davis et al., 2013). In this respect, new dynamic and interactive technologies can offer new ways of communicating evolutionary time. Thus, the central issue in this research is how dynamic visualizations can facilitate teaching and learning about evolutionary time in educational settings for different purposes. Understanding evolutionary time in this context means: a) to be able to order events, b) to locate events in time, c) to comprehend concurrent events, d) to estimate time intervals, and e) to compare the duration of time intervals (Hidalgo, Fernando, \& Otero, 2004).

Based on the findings in this research, I claim that addressing $a, b$ and $\mathrm{c}$ is possible by using well-designed visualizations, which will be elaborated below. Addressing $\mathrm{d}$ and e is more complicated, since it involves several abilities: finding the time of onset and termination and then estimating the difference when calculating an interval. Even more mathematical operations are involved in comparisons of time intervals, but well-chosen and well-designed visualizations can offer ways to visually aid the perception of the length of one or several time intervals. An important problem affecting the comprehension of several of these aspects of time is related to the threshold concept of temporal scales, i.e., moving between scales (Meyer \& Land, 2005; Ross et al., 2010). The problem with visualizing temporal scales of different magnitudes was evident in both papers, manifested as conflicting design issues; for 
example, the use of various time rates in animations, which facilitates perceiving details and might improve the narrative structure (BoydDavis, 2013b; Vít \& Bláha, 2012), simultaneously reinforces intuitive errors in users (Lee et al., 2011).

This research shows that careful choice and informed use of visualizations matters, and that different visualizations will be best suited for different educational purposes (Phillips, Norris, \& Macnab, 2010). This will be elaborated on in the following text. First, findings from the two studies will be discussed from a wider perspective. Then, implications for teaching and learning will be covered. This will be followed by the major conclusions, finally ending with suggestions for future research.

\subsection{Animated Timelines in Visualizations of Evolutionary Time}

Timelines have been used at least during the past 250 years (BoydDavis, 2012), but new technologies extend the possibilities to express time in timelines, e.g. animated timelines. In paper I, the combination of two design features in animated timelines was investigated in relation to how evolutionary time is comprehended: a) number of timelines, and b) constant versus variable rate of time. In the following I will discuss the findings in light of prior research and important aspects regarding the use of animated timelines in education.

Five aspects were possible to discern that could influence how animated timelines were comprehended: whether the representation of time did or did not involve temporal shifts in relation to "real" time (Lee, et al., 2011; Vít \& Bláha, 2012), the structure of the narrative in the animation (Boyd-Davis, 2013b), the cognitive load (Mayer \& Moreno, 2003), the temporal resolution (i.e. the time rate, especially during event "intensive" periods), and the spatial resolution of the timeline (i.e. how sparsely events were distributed). The factors that were anticipated to impair, distort or aggravate comprehension of temporal aspects were: high cognitive load, and low temporal and spatial resolution. Narrative flow (primarily the temporal distribution of events) and distortion of time (in the form of variable time rates) were expected to be advantageous or disadvantageous under different circumstances, depending on the educational objective.

A compilation of how the different animations relate to the abovementioned aspects is shown in Table 7. 
Table 7. A comparison of important aspects in the different animations.

\begin{tabular}{|c|c|c|c|c|c|}
\hline Animation & $\begin{array}{c}\text { Time } \\
\text { distortion } \\
\text { (variable } \\
\text { time rate) } \\
\end{array}$ & $\begin{array}{l}\text { Narrative } \\
\text { flow (the } \\
\text { temporal } \\
\text { distribution } \\
\text { of events } \\
\text { displayed) }\end{array}$ & $\begin{array}{l}\text { Cognitive } \\
\text { load due to } \\
\text { split atten- } \\
\text { tion (sever- } \\
\text { al timelines } \\
\text { and/or } \\
\text { variable } \\
\text { time rate) }\end{array}$ & $\begin{array}{c}\text { Temporal } \\
\text { resolution } \\
\text { in part III } \\
\text { (how } \\
\text { quickly } \\
\text { events are } \\
\text { displayed) } \\
\end{array}$ & $\begin{array}{c}\text { Spatial } \\
\text { resolution } \\
\text { in part III } \\
\text { (how } \\
\text { densely } \\
\text { events are } \\
\text { positioned } \\
\text { on the } \\
\text { timeline) }\end{array}$ \\
\hline $\begin{array}{l}\text { A. } 1 \text { timeline } \\
\text { and constant } \\
\text { time rate }\end{array}$ & no & uneven & low & poor & poor \\
\hline $\begin{array}{l}\text { B. } 1 \text { timeline } \\
\text { and variable } \\
\text { time rate }\end{array}$ & yes & even & medium & good & poor \\
\hline $\begin{array}{l}\text { C. } 3 \text { timelines } \\
\text { and constant } \\
\text { time rate }\end{array}$ & no & uneven & high & poor & good \\
\hline $\begin{array}{l}\text { D. } 3 \text { timelines } \\
\text { and variable } \\
\text { time rate }\end{array}$ & yes & even & medium & good & good \\
\hline
\end{tabular}

The major findings were generally in line with what was predicted: a low spatial resolution, that is, animations with only one timeline (A and B), most notably gave rise to poor results, concerning the event-filled period close to the present time. This was particularly pronounced regarding items related to finding events at specific times, and estimating a time interval. Prior research has shown that there is a tendency to underestimate durations for large temporal magnitudes (Catley \& Novick, 2009) and to overestimate small numbers (Dehaene et al., 2008). This is what has been called the compression effect (Longo \& Lourenco, 2007), towards a range that is familiar to human experiences. Because of the compression effect Lee et al. (2011) recommend carefulness when using visualizations with alterations in time rate, since this actually reinforces the intuitive error. This is a probable reason for the bad result concerning comparisons of durations in the animation with a decreasing time pace and several timelines (animation D).

Assessing the relative order of events was the least demanding task for the participants, independent of which animation was used. This is not surprising, since it was possible to comprehend the order without reference to the representation of time. This applies to items related to concurrency as well, but in that case indications of cognitive load due to split attention (Mayer \& Moreno, 2003; Peterson, 1999) were indicated in the animation that displayed several timelines and a constant time rate (animation C). Generally, a representation with several timelines 
and a decreasing time rate gave rise to the best results, with one notable exception: comparisons of durations involving time spans that spanned temporal shifts.

A contributing factor in this case might also be the high cognitive load. When designing animations involving evolutionary time, other aspects have to be considered, for example that much more is known about the recent past compared to more distant past (Boyd-Davis, 2012). This aggravates the problem with uneven distribution of events, which can impair the narrative of an animation (Vít \& Bláha, 2012). Thus, informed decisions have to be made when choosing an appropriate visualization for specific educational purposes. In contrast to some prior research (Midtbø, Clarke, \& Fabrikant, 2007), this study indicates that the design of the time representation does matter, and can affect learners' abilities to comprehend at least some temporal aspects.

\subsection{Aspects of Temporal Representations in Touch Sensitive Interfaces}

The visualization used in paper II, DeepTree, was, contrary to the animation in paper I, open-ended and with no predetermined sequence of events. The level of interactivity and the user control was considerably higher compared with the animation in paper I. DeepTree actually required interactivity on behalf of the user, in order for it to respond. Several aspects of the interface of DeepTree made it a highly embodied experience: for example, the touch interface and the zooming experience, which bears strong resemblance to travelling along a road with signs and crossings that pass along the way. Zooming is perhaps the most striking feature of DeepTree, which evokes strong reactions among users.

However, since the study concerning DeepTree was performed under clinical conditions with only ten persons from the same age group and educational background, and with a large majority of females, the results are not readily generalizable. Despite this, the interviews provided rich insight into which possibilities and problems are associated with this kind of dynamic visualization involving evolutionary time.

\subsection{The zoom aspect of DeepTree}

One of the finding in paper II was that there was considerable variation among students concerning the time spent on zooming and the intensity of zooming events. All students, except one, comprehended the 
zooming feature as a movement. This student did not express any particular interpretation of zooming, but could correctly identify the origin of life and incorrectly perceived the implicit y-axis as a coherent temporal axis. Furthermore, the participants were distributed equally among those who made many utterances about zooming as a movement in time or as a movement in space (i.e. within the tree metaphor). The direction of zooming movements in time was dominated by the forward/backward metaphor, and the direction of zooming movements in the tree metaphor was dominated by the nearer/further metaphor.

Viewed through the theoretical lens of embodied cognition, several of the results make sense. It is apparent that most participants experience zooming as striking, probably because it is very similar to travelling along a road. This is even further reinforced by the touch sensitive interface, which acts similar to a throttle control. The experience is very immersive, and gave rise to many affective reactions.

According to Wilson (2002), embodied cognition should preferably be considered according to separate claims made by the framework. I will respond to three of these claims, namely: 1) that cognition is situated, 2) that we off-load cognitive work to the environment, and 3) that the environment constitutes a part of the cognitive system. Claim 1 applies well to the included studies, since the participants were situated in a particular environment and forced to act and perceive using a specific animation, and solving specific tasks. Claim 2 applies as well, as the information was held in the animations, and could be accessed on demand by the user by interactions. This was most pronounced in DeepTree. Furthermore, DeepTree constituted a manifestation of claim 3, since participants cognitively could simulate the outcome of hypothetical questions and then perform the actual operation on the tabletop, to test their simulated outcome. Moreover, it was possible for the users to develop their understanding by a dynamic interplay between the cognitive simulations, which could be tested and modified, using the external simulation on the board.

\subsubsection{The time aspect of DeepTree}

One of the major findings in paper II was that the application, in its present design, does not help students very much to understand evolutionary time. The only temporal aspect that could easily be discerned to comprehend relative order of events. However, the experience of working with DeepTree had very little effect on student's perception of evolutionary time. For example, the student's prediction of the time for the dinosaur development before working with DeepTree with their an- 
swers after the session were very disappointing. Only three of ten students had changed their mind to more correct answers.

On one hand, this might not be so strange, since phylogenetic trees originally were developed to illustrate kinship. However, with the possibilities available today, an interactive tree could also be designed to fill temporal relationships. For example, to shift moods between different options like time or kinship.

To prioritize temporal aspects in a visualization such as DeepTree, the ability to find specific times in an evolutionary tree should be facilitated not only by labelling important events with the approximate time but also somehow inform users if there is a timeline, and what kind of scale it has. In this way the ability to perceive the order of events, concurrency of events and periods would also be facilitated.

In its present form, DeepTree may be associated with several temporal-related misunderstandings (see below).

\subsubsection{Misinterpretations induced by DeepTree}

Several misinterpretations were observed, some of which have been reported in prior research (Meir et al., 2007): that the branch tips represent present time, that there is an implicit coherent timeline along the $y$-axis, and that more branching points infer a longer time. In addition, an unanticipated type of misinterpretation was observed, which arose from the zooming feature: that zooming time corresponds to real evolutionary time, which is not the case.

One interpretation of the results is that the zooming experience can contribute to learning but also cause misinterpretations. That time often is thought of (and expressed) metaphorically as space is well known (Boroditsky, 2000; Lakoff \& Johnson, 1980, 1999). Since time is explicitly expressed in DeepTree with the origin of life situated at the root, and that many of the species located in the canopy are contemporary, it is not very surprising that zooming can be assumed to correspond to a passage in time. However, if time is perceived as distance, then longer experienced distance means longer time.

Another misinterpretation was that many of the participants thought that more nodes meant longer time. A parallel misinterpretation in prior research was observed by Meir et al. (2007), who found that more intervening nodes between two species was interpreted as a sign of less relatedness.

In the DeepTree application, another probable source of misinterpretation is that more nodes confer longer zoom time. All participants assumed that unequal zooming time also meant unequal evolutionary time, which is not the case. The zooming time from the origin of life to contemporary species differs much more than would be explained by 
their evolutionary history. This was a misinterpretation all participants made. Thus, using embodied experiences can be a useful method to make meaning but can also cause grave misinterpretations.

\subsection{Implications for Teaching and Learning about Evolution}

As a teacher with long experience of education at upper secondary level, I know that teaching in real world setting is multifaceted, and dependent on a variety of factors. Thus, the use of visualizations such as the ones investigated in this thesis should also be considered from a wider perspective. To successfully teach and learn with visualizations, representational competence is crucial both for the teachers and the students. On the part of the teacher, important knowledge concerns which among the many available animations to choose, considering the educational purpose, as well as the ability to arrange the learning situation and how to scaffold the visualizations used. To use visualizations in educational settings in an optimal way, supplementary discussion is needed since visual tools always need explanations.

A result emerging from the thesis research supports the notion that an awareness of the different important factors in relation to the educational objective is the key to successful use of visualizations. In the particular case of paper I (visualization of evolutionary time in hominin history), design issues affecting the cognitive load and narrative have to be acknowledged, as well as the importance of pre-knowledge and the objective of the learning situation. "No size fits all" as it were - different representations suit different educational purposes. To give a simple and proportionally correct rendering of the temporal sequence, in order to highlight how insignificant is the time our species has existed in comparison to the origin of life, animation A with one timeline and a constant time rate will serve well. But if it is important to be able to identify and reason about subtler and/or concurrent events, animation D would be preferable.

Since the study in paper II was conducted in a clinical environment, it is harder to extrapolate to real world settings, but the results indicate that this kind of new technology has the potential to make strong impressions on learners, not the least by connecting to bodily experiences (e.g. travelling). Zooming can be an embodied and affectively engaging feature, but the experience has to serve a function in relation to the intended purpose. The results also reveal that this potential has to be framed and guided, since it is easy to misinterpret several of the features in the application. Unity and diversity among organisms is well 
communicated, but further development is required if educational purposes concerning temporal aspects in evolution are to be fulfilled.

A viable path to using visualizations of evolutionary time is through the use of multiple representations (Ainsworth, 1999), which reduces the number of compromises needed. Even better would be if different representations could be built into the same application, so that it would be possible to switch between representational "modes". One such example would be the way phylogenetic trees can be depicted differently depending on how the temporal factor is expressed.

A common problem facing users of visualizations is high cognitive load. In the case of the visualization in paper I it could result from distortions of time perception due to different time rate or variable scales, or due to the split attention effect. One way to circumvent this kind of problem is to provide the user with a high degree of control and interactivity. For example, the abilty to zoom in on specific parts of a timeline by pinching, to access information that needs more details. Moreover, the availability of the visualization can be important. If it is possible to revisit the animation any time and from many places, as is the case if it is available on the internet, the opportunity to investigate the information becomes better, thus enhancing the learning opportunities.

\subsection{Summary and Conclusion}

As mentioned at the beginning of this thesis, several immensely important contemporary problems facing the human species require scientific literacy to be addressed in a rational way. The issues mentioned require knowledge about evolution, including evolutionary time, in order to understand, form opinions and take proper action. In my own opinion, education and scientific outreach are the only viable routes to increase scientific literacy, so any tool that provides support and improvements to education is valuable. One novel type of tool used in education is interactive dynamic visualizations; and how these can facilitate teaching and learning about evolution and evolutionary time is the theme of this thesis.

Evolutionary trees have been used for more than 150 years now and modern timelines more than 250 years. New technologies have extended the opportunities that these representations can offer, especially in communicating dynamic processes and in possibilities to interact. Much research has been devoted to how static evolutionary trees and timelines are comprehended among learners, but there are still gaps in knowledge concerning how new dynamic visualizations are understood. 
This thesis is a contribution to fill some of the gaps in existing knowledge. The major findings in this thesis are as follows:

- Several factors should be considered when designing and choosing among the available visualizations of predetermined sequences in evolutionary time for educational settings. Depending on the specific educational object, different aspects will be important.

- If it is important to discern details in minor parts of a depicted evolutionary history, then a change of rate could be favoured. This might also improve the narrative structure if it is a predetermined sequence of events, for example in an animation.

- A drawback with altering time rate is that it might reinforce an intuitive tendency to underestimate very long time periods and overestimate the duration of very short time periods. Thus, the use of temporal changes should be used carefully, especially if it is important to understand comparisons of time intervals.

- The cognitive load imposed on the learner has to be considered. This factor is especially relevant concerning concurrency of events, and even more so if the representation of time is multifaceted or complex, since the split attention effect might impair the comprehension of events.

An alternative way to address evolutionary time is by means of interactive features, such as touch sensitive interfaces that afford zooming. The highly embodied and immersive experience of this kind of applications can affect learners in a strong way. This thesis has shown that:

- zooming can be interpreted in different ways

- zooming can lead till reinforced misinterpretations

- with well-guided use, the potential for learning is very promising.

\subsection{Future Research}

The results from the studies included in this thesis uncover potential new research questions and themes. Visualizations aiming to enhance understanding of the combined effect of the components involved in the process of evolution (i.e., evolutionary time in combination with large populations, small probabilities of mutations in certain genes, and natural selection) would be most interesting, since this targets the complex mechanisms of evolution by natural selection. 
A second area of research that would be very interesting to follow up on, would be how the combination of the opportunities offered by new interactive and immersive technologies can be combined with the informed use of knowledge from embodied cognition to facilitate learning. An example would be to build upon the strong experience that zooming is perceived as travelling but deliberately use the visual metaphor in an informed way to exploit the possibility to emphasize temporal aspects.

A third interesting field would be to analyze how informed use of multiple representations concerning evolutionary time could contribute to teaching and learning. For example, presentation of a phylogenetic tree in which different aspects could be prioritized (e.g., correct chronological time or the most effective way to visualize relationship). 


\section{References}

Ainsworth, S. (1999). The functions of multiple representations. Computers \& Education, 33(2-3), 131-152.

Ainsworth, S. (2008). How do animations influence learning. Current perspectives on pognition, learning, and instruction: Recent innovations in educational technology that facilitate student learning, $37-67$.

Allegre, C. J., Manhes, G., \& Göpel, C. (1995). The age of the Earth. Geochimica et Cosmochimica Acta, 59(8), 1445-1456.

Andersson, B., \& Wallin, A. (2006). On developing content-oriented theories taking biological evolution as an example. International Journal of Science Education, 28(6), 673-695. https://doi.org/10.1080/09500690500498385

Ault, C. R. (1981). Children's concepts about time no barrier to understanding the geologic past. (Doctoral dissertation). Cornell University, Ithaca.

Ault, C. R. (1982). Time in geological explanations as perceived by elementary school students. Journal of Geological Education, (30), 304-309.

Baddeley, A. (2003). Working memory: looking back and looking forward. Nature Reviews Neuroscience, 4(10), 829-839. https://doi.org/10.1038/nrn1201

Basel, N., Harms, U., \& Prechtl, H. (2013). Analysis of students' arguments on evolutionary theory. Journal of Biological Education, 47(4), 192-199. https://doi.org/10.1080/00219266.2013.799078

Baum, D. A., Smith, S. D., \& Donovan, S. S. S. (2005). The tree-thinking challenge. $\quad$ Science, 979 (5750), https://doi.org/10.1126/science.1117727

Besterman, H., \& Baggott La Velle, L. (2007). Using human evolution to teach evolutionary theory. Journal of Biological Education, 41(2), 76-81.

Billingsley, B., Brock, R., Taber, K. S., \& Riga, F. (2016). How students view the boundaries between their science and religious education concerning the origins of life and the universe. Science Education, 10O(3), 459-482. https://doi.org/10.1002/sce.21213

Block, F., Horn, M. S., Phillips, B. C., Diamond, J., Evans, E. M., \& Shen, C. (2012). The deeptree exhibit: Visualizing the tree of life to facilitate informal learning. IEEE Transactions on Visualization and Computer Graphics, 18(12), 2789-2798.

Blumenschine, R. J., Peters, C. R., Masao, F. T., Clarke, R. J., Deino, A. L., Hay, R. L., ... Ebert, J. I. (2003). Late Pliocene homo and homi- 
nid land use from western Olduvai Gorge, Tanzania. Science, 299(5610), 1217-1221. https://doi.org/10.1126/science.1075374

Bohlin, G. (2017). Evolving germs - Antibiotic resistance and natural selection in education and public communication. Linköping: Linköping University Electronic Press. Retrieved from http://public.eblib.com/choice/publicfullrecord.aspx?p=5085276

Boroditsky, L. (2000). Metaphoric structuring: Understanding time through spatial metaphors. Cognition, 75(1), 1-28.

Boyd-Davis. (2013a, January). Inventing the timeline: a history of visual history. Oral presented at the Meeting at The Information Design Association, London. Retrieved from https://vimeo.com/58980227

Boyd-Davis, S. (2012). History on the line: time as dimension. Design Issues, 28(4), 4-17.

Boyd-Davis, S. (2013b, January). Inventing the timeline: a history of visual history. Mp3 presented at the A presentation to the Information Design Association, London.

Boyd-Davis, S., Bevan, E., \& Kudikov, A. (2013). Just in time: Defining historical chronographics. In J. P. Bowen, S. Keene, \& K. Ng (Eds.), Electronic Visualisation in Arts and Culture (pp. 243-257). London: Springer London. https://doi.org/10.1007/978-1-4471-5406-8_17

Brown, P., Sutikna, T., Morwood, M. J., Soejono, R. P., Saptomo, E. W., Due, R. A., \& others. (2004). A new small-bodied hominin from the Late Pleistocene of Flores, Indonesia. Nature, 431(7012), 1055-1061.

Cassinelli, A., \& Ishikawa, M. (2005). Khronos projector. In ACM SIGGRAPH 2005 Emerging technologies on - SIGGRAPH 'O5 (p. 10). Los Angeles, California: ACM Press. https://doi.org/10.1145/1187297.1187308

Catley, K. M. (2006). Darwin's missing link-a novel paradigm for evolution education. Science Education, 90(5), 767-783. https://doi.org/10.1002/sce.20152

Catley, K. M., \& Novick, L. R. (2008). Seeing the wood for the trees: An Analysis of Evolutionary Diagrams in Biology Textbooks. BioScience, 58(10), 976-987. https://doi.org/10.1641/B581011

Catley, K. M., \& Novick, L. R. (2009). Digging deep: Exploring college students' knowledge of macroevolutionary time. Journal of Research in Science Teaching, 46(3), 311-332. https://doi.org/10.1002/tea.20273

Cheek, K. A. (2010). Factors underlying students' conceptions of deep time: An exploratory study. Durham University. Retrieved from http://etheses.dur.ac.uk/277/

Cheek, K. A. (2012). Students'understanding of large numbers as a key factor in their understanding of geologic time. International Journal 
of Science and Mathematics Education, 10(5), 1047-1069.

Cheek, K. A. (2013a). Exploring the relationship between students' understanding of conventional time and deep (geologic) time. International Journal of Science Education, 35(11), 1925-1945. https://doi.org/10.1080/09500693.2011.587032

Cheek, K. A. (2013b). How geoscience novices reason about temporal duration: the role of spatial thinking and large numbers. Journal of Geoscience Education, 61(3), 334-348.

Clary, R. M., Brzuszek, R. F., \& Wandersee, J. H. (2009). Students' geocognition of deep time, conceptualized in an informal educational setting. Journal of Geoscience Education, 57(4), 275-285.

Cousin, G. (2006). An introduction to threshold concepts. Planet, 17(1), 4-5. https://doi.org/10.11120/plan.2006.00170004

Curtis, H., \& Barnes, N. S. (1989). Biology. New York: Worth Publishers.

Darwin, C. (1859). On the origin of species by means of natural selection. Murray, London.

DeGiorgio, M., Jakobsson, M., \& Rosenberg, N. A. (2009). Explaining worldwide patterns of human genetic variation using a coalescentbased serial founder model of migration outward from Africa. Proceedings of the National Academy of Sciences, 106(38), 1605716062. https://doi.org/10.1073/pnas.0903341106

Dehaene, S., Izard, V., Spelke, E., \& Pica, P. (2008). Log or linear? Distinct intuitions of the number scale in western and amazonian indigene cultures. Science, 320(5880), 1217-1220. https://doi.org/10.1126/science.1156540

Dobzhansky, T. (1973). Nothing in biology makes sense except in the light of evolution. The American Biology Teacher, 35(3), 125-129. https://doi.org/10.2307/4444260

Dodick, J. (2007). Understanding evolutionary change within the framework of geological time. McGill Journal of Education, 42(2), 245-264.

Dodick, J., \& Orion, N. (2003a). Cognitive factors affecting student understanding of geologic time. Journal of Research in Science Teaching , 4O(4), 415-442. https://doi.org/10.1002/tea.10083

Dodick, J., \& Orion, N. (2003b). Measuring student understanding of geological time. Science Education, 87(5), 708-731. https://doi.org/10.1002/sce.1057

Domenjó, C. (2010). The phenomenology of time in interactive visual representations. Hipertext.Net, $8 . \quad$ Retrieved from http://www.upf.edu/hipertextnet/en/numero-

8/time_interaction.html

Driver, R., Leach, J., \& Millar, R. (1996). Young people's images of sci- 
ence. McGraw-Hill Education (UK).

Edsall, R. ., Kraak, M.-J., MacEachren, A. M., \& Peuquet, D. J. (1997). Assessing the effectiveness of temporal legends in environmental visualization. (Vol. 1997, pp. 677-685). Presented at the GIS/LIS '97, Cincinnati.

Feeney, D. (2007). Sather classical lectures : Caesar's calendar : Ancient times and the beginnings of history (1) [Elektronisk resurs].

Fereday, J., \& Muir-Cochrane, E. (2006). Demonstrating rigor using thematic analysis: A hybrid approach of inductive and deductive coding and theme development. International Journal of Qualitative Methods, 5(1), 80-92. https://doi.org/10.1177/160940690600500107

Foreman, N. (2008). Can virtual environments enhance the learning of historical chronology? Instructional Science, 36(2), 155-173. https://doi.org/10.1007/s11251-007-9024-7

Fu, Q., Hajdinjak, M., Moldovan, O. T., Constantin, S., Mallick, S., Skoglund, P., ... Pääbo, S. (2015). An early modern human from Romania with a recent Neanderthal ancestor. Nature, 524(7564), 216219. https://doi.org/10.1038/nature14558

Gentner, D. (2001). Spatial metaphors in temporal reasoning. In Spatial schemas and abstract thought (pp. 203-222). Retrieved from http://groups.psych.northwestern.edu/gentner/newpdfpapers/Gent nero1.pdf

Gilbert, J. K. (2005). Visualization: A metacognitive skill in science and science education. In J. K. Gilbert (Ed.), Visualization in Science Education (pp. 9-27). Dordrecht: Springer Netherlands. https://doi.org/10.1007/1-4020-3613-2_2

Gontier, N. (2011). Depicting the tree of life: the philosophical and historical roots of evolutionary tree diagrams. Evolution: Education and Outreach, 4(3), 515-538. https://doi.org/10.1007/s12052-0110355-0

Green, R. E., Krause, J., Briggs, A. W., Maricic, T., Stenzel, U., Kircher, M., ... Paabo, S. (2010). A draft sequence of the neandertal genome. Science, $328(5979)$, https://doi.org/10.1126/science.1188021

710-722.

Gregory, T. R. (2008). Understanding evolutionary trees. Evolution: Education and Outreach, 1(2), 121-137. https://doi.org/10.1007/s12052-008-0035-x

Gustafsson, B., Hermerén, G., \& Petersson, B. (2006). Good research practice - what is it? : views, guidelines and examples. Stockholm: Vetenskapsrådet.

Halverson, K. L., \& Friedrichsen, P. (2013). Learning tree thinking: developing a new framework of representational competence. In D. 
F. Treagust \& C.-Y. Tsui (Eds.), Multiple Representations in Biological Education (Vol. 7, pp. 185-201). Dordrecht: Springer Netherlands. https://doi.org/10.1007/978-94-007-4192-8_11

Heaton, T. H. (2009). Recent developments in young-earth creationist geology. Science \& Education, 18(10), 1341-1358. https://doi.org/10.1007/s11191-008-9162-6

Hidalgo, A. J., Fernando, I. E. S. S., \& Otero, I. C. E. J. (2004). REEARCH REPORT: An analysis of the understanding of geological time by students at secondary and post-secondary level. International Journal of Science Education, 26(7), 845-857. https://doi.org/10.1080/0950069032000119438

Hublin, J.-J. (2009). The origin of Neandertals. Proceedings of the National Academy of Sciences, 106(38), 16022-16027.

Hublin, J.-J., Ben-Ncer, A., Bailey, S. E., Freidline, S. E., Neubauer, S., Skinner, M. M., ... Gunz, P. (2017). New fossils from Jebel Irhoud, Morocco and the pan-African origin of Homo sapiens. Nature, 546(7657), 289-292.

Huxley, J. (1942). Evolution the modern synthesis. George Allen and Unwin.

Kalyuga, S., Chandler, P., \& Sweller, J. (1999). Managing split-attention and redundancy in multimedia instruction. Applied Cognitive Psychology, 13(4), 351-371. https://doi.org/10.1002/(SICI)1099O720(199908)13:4<351::AID-ACP589>3.0.CO;2-6

Korallo, L., Foreman, N., Boyd-Davis, S., Moar, M., \& Coulson, M. (2012). Can multiple "spatial" virtual timelines convey the relatedness of chronological knowledge across parallel domains? Computers \& Education, 58(2), 856-862. https://doi.org/10.1016/j.compedu.2011.10.011

Lakoff, G. (1999). Philosophy in the flesh: the embodied mind and its challenge to Western thought. New York: New York: Basic Books.

Lakoff, G. (2012). Explaining Embodied Cognition Results. Topics in Cognitive Science, 4(4), 773-785. https://doi.org/10.1111/j.17568765.2012.01222.x

Lakoff, G., \& Johnson, M. (1980). Metaphors we live by. Chicago: Univ. of Chicago Press.

Lawrence, E., \& Henderson, I. F. (2011). Henderson's dictionary of biology [Elektronisk resurs]. Harlow: Benjamin Cummings.

Lee, C., Devillers, R., \& Hoeber, O. (2014). Navigating spatio-temporal data with temporal zoom and pan in a multi-touch environment. International Journal of Geographical Information Science, 28(5), 1128-1148. https://doi.org/10.1080/13658816.2013.861072

Lee, H.-S., Liu, O. L., Price, C. A., \& Kendall, A. L. M. (2011). College students' temporal-magnitude recognition ability associated with 
durations of scientific changes. Journal of Research in Science Teaching, 48(3), 317-335. https://doi.org/10.1002/tea.20401

Libarkin, J. C., Kurdziel, J. P., \& Anderson, S. W. (2007). College student conceptions of geological time and the disconnect between ordering and scale. Journal of Geoscience Education, 55(5), 413-422.

Linn, M. (2003). Technology and science education: Starting points, research programs, and trends. International Journal of Science Education, $25(6)$, https://doi.org/10.1080/09500690305017

$727-758$.

Longo, M. R., \& Lourenco, S. F. (2007). Spatial attention and the mental number line: Evidence for characteristic biases and compression. Neuropsychologia, 45(7), 1400-1407. https://doi.org/10.1016/j.neuropsychologia.2006.11.002

Lyell, C., Sir, \& Deshayes, G. P. (1830). Principles of geology; being an attempt to explain the former changes of the earth's surface, by reference to causes now in operation. (Vol. 3). London,: J. Murray,. Retrieved from https://www.biodiversitylibrary.org/item/107923

MacDonald, T., \& Wiley, E. O. (2012). Communicating Phylogeny: Evolutionary Tree Diagrams in Museums. Evolution: Education and Outreach, 5(1), 14-28. https://doi.org/10.1007/s12052-012-0387-0

Matuk, C., \& Uttal, D. H. (2018). The effects of invention and recontextualization on representing and reasoning with trees of life. $R e$ search in Science Education. https://doi.org/10.1007/s11165-0189761-4

Mayer, R. E., \& Moreno, R. (2003). Nine ways to reduce cognitive load in multimedia learning. Educational Psychologist, 38(1), 43-52.

Mayr, E. (1982). The growth of biological thought: Diversity, evolution, and inheritance. Harvard University Press.

Mayr, E. (2007). What makes biology unique?: considerations on the autonomy of a scientific discipline. Cambridge University Press.

Mayring, P. (2000). Qualitative content analysis. In Qualitative content analysis. Forum: Qualitative Social Research (Vol. 1).

Meir, E., Perry, J., Herron, J. C., \& Kingsolver, J. (2007). College students' misconceptions about evolutionary trees. The American Biology Teacher, 69(7), e71-e76. https://doi.org/10.1662/00027685(2007)69[71:CSMAET]2.0.CO;2

Meyer, J. H., \& Land, R. (2005). Threshold concepts and troublesome knowledge (2): Epistemological considerations and a conceptual framework for teaching and learning. Higher Education, 49(3), $373-388$.

Midtbø, T., Clarke, K. C., \& Fabrikant, S. (2007). Human interaction with animated maps: The portrayal of the passage of time. In 11th Scandinavian Research Conference on Geographical Information 
Science

(pp.

$45^{-60)}$.

Retrieved

from

http://www.researchgate.net/profile/Keith_Clarke2/publication/2 28897062_Human_interaction_with_animated_maps_The_portr ayal_of_the_passage_of_time/links/o912f51356472bod32000000. pdf

Monmonier, M. (1990). Strategies for the visualization of geographic time-series data. Cartographica: The International Journal for Geographic Information and Geovisualization, 27(1), 30-45.

Moreno, R., \& Mayer, R. (2007). Interactive multimodal learning environments: Special issue on interactive learning environments: Contemporary Issues and Trends. Educational Psychology Review, 19(3), 309-326. https://doi.org/10.1007/s10648-007-9047-2

Morrison, D. A. (2014). Is the tree of life the best metaphor, model, or heuristic for phylogenetics? Systematic Biology, 63(4), 628-638. https://doi.org/10.1093/sysbio/syuo26

Nehm, R. H., \& Reilly, L. (2007). Biology majors' knowledge and misconceptions of natural selection. BioScience, 57(3), 263-272. https://doi.org/10.1641/B570311

Ohlsson, S., \& Bee, N. V. (1992). The effect of expository text on students' explanations of biological evolution. Learning Research and Development Center, University of Pittsburgh.

Paas, F., Renkl, A., \& Sweller, J. (2003). Cognitive load theory and instructional design: Recent developments. Educational Psychologist, $38(1), 1-4$.

Paivio, A. (1990). Mental representations: A dual coding approach. Oxford University Press.

Peterson, M. P. (1999). Active legends for interactive cartographic animation. International Journal of Geographical Information Science, 13(4), 375-383. https://doi.org/10.1080/136588199241256

Phillips, L. M., Norris, S. P., \& Macnab, J. S. (2010). Visualization in Mathematics, Reading and Science Education (Vol. 5). Dordrecht: Springer Netherlands. Retrieved from http://link.springer.com/10.1007/978-90-481-8816-1

Piaget, J. (1969). The child's conception of time. London: Routledge \& Kegan Paul.

Pinna, B. (2010). New gestalt principles of perceptual organization: An extension from grouping to shape and meaning1.

Pontzer, H. (2012). Overview of hominin evolution. Nature Education Knowledge, 3(10), 8.

Posner, G. J., Strike, K. A., Hewson, P. W., \& Gertzog, W. A. (1982). Accommodation of a scientific conception: Toward a theory of conceptual change. Science Education, 66(2), 211-227.

Rightmire, G. P. (2009). Middle and later Pleistocene hominins in Afri- 
ca and Southwest Asia. Proceedings of the National Academy of Sciences, 106(38), 16046-16050. https://doi.org/10.1073/pnas.0903930106

Rightmire, G. Philip. (2008). Homo in the middle pleistocene: Hypodigms, variation, and species recognition. Evolutionary Anthropology: Issues, News, and Reviews, 17(1), 8-21. https://doi.org/10.1002/evan.20160

Robson, C. (2011). Real world research : a resource for users of social research methods in applied settings. Chichester: Wiley.

Rosindell, J., Harmon L.J. (2012) "OneZoom: A Fractal Explorer for the Tree of Life" PLoS Biol 10(10): e1001406. (doi:10.1371/journal.pbio.1001406)

Ross, P. M., Taylor, C. E., Hughes, C., Whitaker, N., Lutze-Mann, L., Kofod, M., \& Tzioumis, V. (2010). Threshold concepts in learning biology and evolution. Biology International, 47, 47-54.

Rowbottom, D. P. (2007). Demystifying threshold concepts. Journal of Philosophy of Education, 41(2), 263-270. https://doi.org/10.1111/j.1467-9752.2007.00554.x

Russell, R. J. (1984). The growth of biological thought: Diversity, evolution, and inheritance. Ethology and Sociobiology, 5(1), 63-64. https://doi.org/10.1016/0162-3095(84)90038-4

Sanders, M. F., \& Bowman, J. L. (2016). Genetic analysis : an integrated approach. Boston: Pearson.

Schnotz, W. (2002). Commentary: Towards an integrated view of learning from text and visual displays. Educational Psychology Review, 14(1), 101-120. https://doi.org/10.1023/A:1013136727916

Schopf, J. W. (1993). Microfossils of the early archean apex chert: New evidence of the antiquity of life. Science, New Series, 260(5108), $640-646$.

Shtulman, A. (2006). Qualitative differences between naïve and scientific theories of evolution. Cognitive Psychology, 52(2), 170-194. https://doi.org/10.1016/j.cogpsych.2005.10.001

Sjøberg, S. (2010). Naturvetenskap som allmänbildning: en kritisk ämnesdidaktik (3., rev. uppl..). Lund: Lund : Studentlitteratur.

Smith, M. U. (2010a). Current status of research in teaching and learning evolution: I. philosophical/epistemological issues. Science \& Education, 19(6-8), 523-538. https://doi.org/10.1007/s11191-0099215-5

Smith, M. U. (2010b). Current status of research in teaching and learning evolution: II. Pedagogical issues. Science \& Education, 19(6-8), 539-571. https://doi.org/10.1007/s11191-009-9216-4

Stephens, S. (2012). From tree to map: Using cognitive learning theory to suggest alternative ways to visualize acroevolution. Evolution: 
Education and Outreach, 5(4), 603-618. https://doi.org/10.1007/s12052-012-0457-3

Tibell, L. A. E., \& Harms, U. (2017). Biological principles and threshold concepts for understanding natural selection: Implications for developing visualizations as a pedagogic tool. Science \& Education, 26(7-9), 953-973. https://doi.org/10.1007/s11191-017-9935-x

Trend, R. (1998). An investigation into understanding of geological time among 10- and 11-year-old children. International Journal of Science Education, 2O(8), 973-988. https://doi.org/10.1080/0950069980200805

Trend, R. (2000). Conceptions of geological time among primary teacher trainees, with reference to their engagement with geoscience, history, and science. International Journal of Science Education, 22(5), 539-555. https://doi.org/10.1080/095006900289778

Trend, R. (2001a). An investigation into the understanding of geological time among 17-year-old students, with implications for the subject matter knowledge of future teachers. International Research in Geographical and Environmental Education, 10(3), 298-321. https://doi.org/10.1080/10382040108667447

Trend, R. (2001b). Deep time framework: A preliminary study of U.K. primary teachers' conceptions of geological time and perceptions of geoscience. Journal of Research in Science Teaching, 38(2), 191221. https://doi.org/10.1002/1098-2736(200102)38:2<191::AIDTEA1003>3.0.CO;2-C

Truscott, J. B., Boyle, A., Burkill, S., Libarkin, J., \& Lonsdale, J. (2006). The concept of time: can it be fully realised and taught? Planet, (17), 21-23.

Vekiri, I. (2002). What Is the value of graphical displays in learning? Educational Psychology Review, 14(3), 261-312. https://doi.org/10.1023/A:1016064429161

VERBI Software. (2017). [MAXQDA]. Berlin, Germany: VERBI Software. Retrieved from https://www.maxqda.com

Villmoare, B., Kimbel, W. H., Seyoum, C., Campisano, C. J., DiMaggio, E. N., Rowan, J., ... Reed, K. E. (2015). Early Homo at 2.8 Ma from Ledi-Geraru, Afar, Ethiopia. Science, 347(6228), 1352-1355. https://doi.org/10.1126/science.aaa1343

Vít, L., \& Bláha, J. D. (2012). A study of the user friendliness of temporal legends in animated maps. AUC GEOGRAPHICA, 47(2), 5361.

Wallin, A. (2004). Evolutionsteorin i klassrummet: på väg mot en ämnesdidaktisk teori för undervisning i biologisk evolution. Göteborg: Acta Universitatis Gothoburgensis.

Wilson, M. (2002). Six views of embodied cognition. Psychonomic Bul- 
letin \& Review, 9(4), 625-636.

Wittrock, M. C. (1989). Generative processes of comprehension. Educational Psychologist, 24(4), 345-376.

Wood, B. (2010). Reconstructing human evolution: Achievements, challenges, and opportunities. Proceedings of the National Academy of Sciences, 107(Supplement_2), 8902-8909. https://doi.org/10.1073/pnas.1001649107

Yasri, P., \& Mancy, R. (2014). Understanding Student Approaches to Learning Evolution in the Context of their Perceptions of the Relationship between Science and Religion. International Journal of Science Education, $36(1)$, https://doi.org/10.1080/09500693.2012.715315

24-45. 


\section{Appendix I}

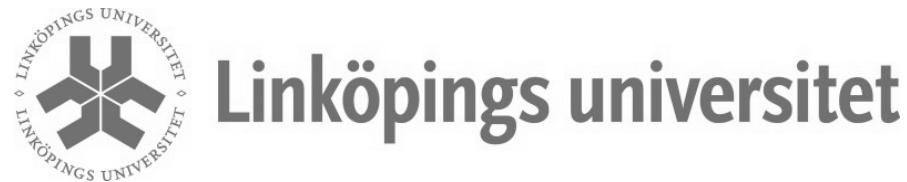

\section{Deltagandeavtal}

Detta avtal är ett medgivande till materialanvändning från den som deltagit i en enkätundersökning och skärminspelning vid datoranvändande med avsikt att ge råmaterial till forskning, primärt vid institutionerna ITN och ISV vid Linköpings universitet.

Användande av materialet

Användande av materialet avser analys av deltagarnas svar samt interaktion med maskin- och mjukvara. Materialet kommer huvudsakligen att analyserat i aggregerat tillstånd. Råmaterialet kommer att förvaras på ett säkert sätt och ej sprids utanför den inblandade forskargruppen.
$\square$ Jag medger
att- upptaget material från enkät och skärminspelning där jag
$\square$ Jag medger ej medverkar får användas i forskningssyfte, förutsatt att det hanteras i enighet med vedertagen svensk forskningsetik.

Presentation av resultat från studien
$\square$ Jag medger
att enkätmaterial, avidentifierade och anonymiserade får
$\square$ Jag medger ej användas i samband med presentationer och publicering av studiens resultat.

$\square$ Jag medger
$\square$ Jag medger ej

att skärminspelade sekvenser där jag medverkar får användas i samband med presentationer och publicering av studiens resultat förutsatt att materialet är avidentifierat och anonymt.

\section{Ångerrätt}

Jag kan när jag vill ändra mina nuvarande medgivanden och avbryta mitt deltagande i studien. Det uppdaterade avtalet träder i kraft när det mottages av kontaktpersonen och gäller ej retroaktivt avseende publicering utförd $\mathrm{i}$ enighet med tidigare avtal.

\section{Underskrift}

\begin{tabular}{|l|l|}
\hline Namn (textat) & Personnummer \\
\hline Ort och datum & \\
\hline Underskrift & \\
\hline
\end{tabular}

Kontaktperson:

Namn: Jörgen Stenlund E-post: jorgen.stenlund@oru.se

Adress: $\quad$ Linköpings universitet, ISV, SE-601 74 Norrköping 



\section{Appendix II}

\section{Avtal avseende användningsbegränsning av forskningsmaterial}

Detta avtal är ett medgivande till materialanvändning från den som deltagit vid en bild och/eller ljudupptagning med avsikt att ge råmaterial till forskning, primärt vid institutionerna ITN och ISV vid Linköpings universitet.

\section{Allmänt användande av materialet}

Allmänt användande av materialet avser t.ex. analys av deltagarnas interaktion med maskin- och mjukvara. Det innebär att materialet ej sprids utanför de inblandade forskargrupperna.

$\square$ Jag medger

$\square$ Jag medger ej

Att upptaget bild- och ljudmaterial där jag medverkar får användas i forskningssyfte och datorbehandlas, förutsatt att det hanteras i enighet med vedertagen svensk forskningsetik.

\section{Utdrag ur materialet för användning vid presentationer}

Det huvudsakliga syftet med att använda utdrag ur materialet är att kunna visa på specifika situationer där beteenden exponeras som bedöms vara relevanta i relation till forskningen.

$\square$ Jag medger

$\square$ Jag medger ej

Att utdrag ur upptaget bild- och ljudmaterial där jag medverkar får användas vid presentationer anknytande till forskning, förutsatt att mitt namn döljs.

\section{Utdrag ur materialet för användning vid elektronisk publicering}

Elektronisk publicering är en möjlighet att sprida kunskap om forskning vid Linköpings universitet, primärt till andra forskare men även till allmänheten. Bilder och videoutdrag underlättar förståelsen för sampresenterat skriftligt material och är ett ypperligt sätt att visa intressanta exempel.

Jag medger att utdrag ur upptaget bild- och ljudmaterial där jag medverkar får användas vid elektronisk publicering anknytande till forskning, förutsatt att mitt namn döljs.

$\square$ Jag medger att endast stillbildsutdrag ur upptaget bildmaterial där jag medverkar får användas vid elektronisk publicering anknytande till forskning, förutsatt att mitt namn döljs.

Jag medger inget användande vid elektronisk publicering av utdrag ur upptaget bild- eller ljudmaterial där jag medverkar. 


\section{Utdrag ur materialet för användning vid tryckning.}

Forskningsmaterial publiceras oftast i tryckt form och fotografier eller utvalda stillbilder ur videosekvenser kan förtydliga budskapet. Publicering sker mestadels i vetenskapliga tidsskrifter och i samband med forskningsrelaterade konferenser.

$\square$ Jag medger

$\square$ Jag medger ej

Att utdrag ur upptaget bildmaterial där jag medverkar får användas vid publicering $\mathrm{i}$ tryckt form, förutsatt att mitt namn döljs.

\section{Ångerrätt}

Jag förbehåller mig rätten att vid senare datum ändra mina nuvarande medgivanden, varvid jag insänder en uppdaterad version av detta avtal till nedanstående kontaktperson. Det uppdaterade avtalet träder i kraft när det mottages av kontaktpersonen och gäller ej retroaktivt avseende publicering utförd i enighet med tidigare avtal.

\section{Kontaktperson}

Namn: Jörgen Stenlund

E-post: $\quad$ jorgen.stenlund@oru.se

Adress: Örebro universitet,

Institutionen för naturvetenskap och teknik,

70182 Örebro

\section{Underskrift}

\begin{tabular}{|l|l|}
\hline Namn (textat) & Personnummer \\
\hline Ort och datum & \\
\hline Underskrift \\
\end{tabular}




\section{Papers}

The papers associated with this thesis have been removed for copyright reasons. For more details about these see:

http://urn.kb.se/resolve?urn=urn:nbn:se:liu:diva-154619 
Studies in Science and Technology Education

ISSN 1652-5051

fontD

1. Margareta Enghag (2004): MINIPROJECTS AND CONTEXT RICH PROBLEMS -

Case studies with qualitative analysis of motivation, learner ownership and competence in small group work in physics. (licentiate thesis) Linköping University

2. Carl-Johan Rundgren (2006): Meaning-Making in Molecular Life Science Education - upper secondary school students' interpretation of visualizations of proteins. (licentiate thesis) Linköping University

3. Michal Drechsler (2005): Textbooks', teachers', and students' understanding of models used to explain acid-base reactions. ISSN: $1403-8099$, ISBN: 91-85335-40-1. (licentiate thesis) Karlstad University

4. Margareta Enghag (2007): Two dimensions of Student Ownership of Learning during Small-Group Work with Miniprojects and context rich Problems in Physics. ISSN: 1651-4238, ISBN: 91-85485-31-4. (Doctoral Dissertation) Mälardalen University

5. Maria Åström (2007): Integrated and Subject-specific. An empirical exploration of Science education in Swedish compulsory schools. (Licentiate thesis) Linköping university

6. Ola Magntorn (2007): Reading Nature: developing ecological literacy through teaching. (Doctoral Dissertation) Linköping University

7. Maria Andreé (2007): Den levda läroplanen. En studie av naturorienterande undervisningspraktiker i grundskolan. ISSN: 1400-478X, HLS Förlag: ISBN 978-917656-632-9 (Doctoral Dissertation, LHS)

8. Mattias Lundin (2007): Students' participation in the realization of school science activities.(Doctoral Dissertation) Linköping University

9. Michal Drechsler (2007): Models in chemistry education. A study of teaching and learning acids and bases in Swedish upper secondary schools ISBN 978-91-7063-1122 (Doctoral Dissertation) Karlstad University

10. Proceedings from FontD Vadstena-meeting, April 2006.

11. Eva Blomdahl (2007): Teknik i skolan. En studie av teknikundervisning för yngre skolbarn. ISSN: 1400-478X, HLS Förlag: ISBN 978-91-7656-635-o (Doctoral Dissertation, LHS)

12. Iann Lundegård (2007): På väg mot pluralism. Elever i situerade samtal kring hållbar utveckling. ISSN:1400-478X, HLS Förlag: ISBN 978-91-7656-642-8 (Doctoral Dissertation, LHS)

13. Lena Hansson (2007): "Enligt fysiken eller enligt mig själv?” - Gymnasieelever, fysiken och grundantaganden om världen. (Doctoral Dissertation) Linköping University.

14. Christel Persson (2008): Sfärernas symfoni i förändring? Lärande i miljö för hållbar utveckling med naturvetenskaplig utgångspunkt. En longitudinell studie i grundskolans tidigare årskurser. (Doctoral Dissertation) Linköping University

15. Eva Davidsson (2008): Different Images of Science - a study of how science is constituted in exhibitions. ISBN: 978-91-977100-1-5 (Doctoral Dissertation) Malmö University

16. Magnus Hultén (2008): Naturens kanon. Formering och förändring av innehållet i folkskolans och grundskolans naturvetenskap 1842-2007. ISBN: 978-91-7155-612-7 (Doctoral Dissertation) Stockholm University

17. Lars-Erik Björklund (2008): Från Novis till Expert: Förtrogenhetskunskap i kognitiv och didaktisk belysning. (Doctoral Dissertation) Linköping University.

18. Anders Jönsson (2008): Educative assessment for/of teacher competency. A study of assessment and learning in the "Interactive examination" for student teachers. ISBN: 978-91-977100-3-9 (Doctoral Dissertation) Malmö University 
19. Pernilla Nilsson (2008): Learning to teach and teaching to learn - primary science student teachers' complex journey from learners to teachers. (Doctoral Dissertation) Linköping University

20. Carl-Johan Rundgren (2008): VISUAL THINKING, VISUAL SPEECH - a Semiotic Perspective on Meaning-Making in Molecular Life Science. (Doctoral Dissertation) Linköping University

21. Per Sund (2008): Att urskilja selektiva traditioner i miljöundervisningens socialisationsinnehåll - implikationer för undervisning för hållbar utveckling. ISBN: 978-91-85485-88-8 (Doctoral Dissertation) Mälardalen University

22. Susanne Engström (2008): Fysiken spelar roll! I undervisning om hållbara energisystem - fokus på gymnasiekursen Fysik A. ISBN: 978-91-85485-96-3 (Licentiate thesis) Mälardalen University

23. Britt Jakobsson (2008): Learning science through aesthetic experience in elementary school science. Aesthetic judgement, metaphor and art. ISBN: 978-91-7155-654-7. (Doctoral Dissertation) Stockholm university

24. Gunilla Gunnarsson (2008): Den laborativa klassrumsverksamhetens interaktioner En studie om vilket meningsskapande år 7-elever kan erbjudas i möten med den laborativa verksamhetens instruktioner, artefakter och språk inom elementär ellära, samt om lärares didaktiska handlingsmönster i dessa möten. (Doctoral Dissertation) Linköping University

25. Pernilla Granklint Enochson (2008): Elevernas föreställningar om kroppens organ och kroppens hälsa utifrån ett skolsammanhang. (Licentiate thesis) Linköping University

26. Maria Åström (2008): Defining Integrated Science Education and putting it to test (Doctoral Dissertation) Linköping University

27. Niklas Gericke (2009): Science versus School-science. Multiple models in genetics The depiction of gene function in upper secondary textbooks and its influence on students' understanding. ISBN 978-91-7063-205-1 (Doctoral Dissertation) Karlstad University

28. Per Högström (2009): Laborativt arbete i grundskolans senare år - lärares mål och hur de implementeras. ISBN 978-91-7264-755-8 (Doctoral Dissertation) Umeå University

29. Annette Johnsson (2009): Dialogues on the Net. Power structures in asynchronous discussions in the context of a web based teacher training course. ISBN 978-91977100-9-1 (Doctoral Dissertation) Malmö University

30. Elisabet M. Nilsson (2010): Simulated "real" worlds: Actions mediated through computer game play in science education. ISBN 978-91-86295-02-8 (Doctoral Dissertation) Malmö University

31. Lise-Lotte Österlund (2010): Redox models in chemistry: A depiction of the conceptions held by upper secondary school students of redox reactions. ISBN 97891-7459-053-1 (Doctoral Dissertation) Umeå University

32. Claes Klasander (2010): Talet om tekniska system - förväntningar, traditioner och skolverkligheter. ISBN 978-91-7393-332-2 (Doctoral Dissertation) Linköping University

33. Maria Svensson (2011): Att urskilja tekniska system - didaktiska dimensioner i grundskolan. ISBN 978-91-7393-250-9 (Doctoral Dissertation) Linköping University

34. Nina Christenson (2011): Knowledge, Value and Personal experience - Upper secondary students' use of supporting reasons when arguing socioscientific issues. ISBN 978-91-7063-340-9 (Licentiate thesis) Karlstad University

35. Tor Nilsson (2011): Kemistudenters föreställningar om entalpi och relaterade begrepp. ISBN 978-91-7485-002-4 (Doctoral Dissertation) Mälardalen University

36. Kristina Andersson (2011): Lärare för förändring - att synliggöra och utmana föreställningar om naturvetenskap och genus. ISBN 978-91-7393-222-6 (Doctoral Dissertation) Linköping University

37. Peter Frejd (2011): Mathematical modelling in upper secondary school in Sweden An exploratory study. ISBN: 978-91-7393-223-3 (Licentiate thesis) Linköping University 
38. Daniel Dufåker (2011): Spectroscopy studies of few particle effects in pyramidal quantum dots. ISBN 978-91-7393-179-3 (Licentiate thesis) Linköping University

39. Auli Arvola Orlander (2011): Med kroppen som insats: Diskursiva spänningsfält i biologiundervisningen på högstadiet. ISBN 978-91-7447-258-5 (Doctoral Dissertation) Stockholm University

40. Karin Stolpe (2011): Att uppmärksamma det väsentliga. Lärares ämnesdidaktiska förmågor ur ett interaktionskognitivt perspektiv. ISBN 978-91-7393-169-4 (Doctoral Dissertation) Linköping University

41. Anna-Karin Westman (2011) Samtal om begreppskartor - en väg till ökad förståelse. ISBN 978-91-86694-43-2 (Licentiate thesis) Mid Sweden University

42. Susanne Engström (2011) Att vördsamt värdesätta eller tryggt trotsa. Gymnasiefysiken, undervisningstraditioner och fysiklärares olika strategier för energiundervisning. ISBN 978-91-7485-011-6 (Doctoral Dissertation) Mälardalen University

43. Lena Adolfsson (2011) Attityder till naturvetenskap. Förändringar av flickors och pojkars attityder till biologi, fysik och kemi 1995 till 2007. ISBN 978-91-7459-233-7 (Licentiate thesis) Umeå University

44. Anna Lundberg (2011) Proportionalitetsbegreppet i den svenska gymnasiematematiken - en studie om läromedel och nationella prov. ISBN 978-91-7393-132-8 (Licentiate thesis) Linköping University

45. Sanela Mehanovic (2011) The potential and challenges of the use of dynamic software in upper secondary Mathematics. Students' and teachers' work with integrals in GeoGebra based environments. ISBN 978-91-7393-127-4 (Licentiate thesis) Linköping University

46. Semir Becevic (2011) Klassrumsbedömning i matematik på gymnasieskolans nivå. ISBN 978-91-7393-091-8 (Licentiate thesis) Linköping University

47. Veronica Flodin (2011) Epistemisk drift - genbegreppets variationer i några av forskningens och undervisningens texter i biologi. ISBN 978-91-9795-161-6 (Licentiate thesis) Stockholm University

48. Carola Borg (2011) Utbildning för hållbar utveckling ur ett lärarperspektiv Ämnesbundna skillnader i gymnasieskolan. ISBN 978-91-7063-377-5 (Licentiate thesis) Karlstad University

49. Mats Lundström (2011) Decision-making in health issues: Teenagers' use of science and other discourses. ISBN 978-91-86295-15-8 (Doctoral Dissertation) Malmö University

50. Magnus Oscarsson (2012) Viktigt, men inget för mig. Ungdomars identitetsbygge och attityd till naturvetenskap. ISBN: 978-91-7519-988-7 (Doctoral Dissertation) Linköping University

51. Pernilla Granklint Enochson (2012) Om organisation och funktion av människokroppens organsystem - analys av elevsvar från Sverige och Sydafrika. 978-91-7519-960-3 (Doctoral Dissertation) Linköping University

52. Mari Stadig Degerman (2012) Att hantera cellmetabolismens komplexitet Meningsskapande genom visualisering och metaforer. ISBN 978-01-7519-954-2 (Doctoral Dissertation) Linköping University

53. Anna-Lena Göransson (2012) The Alzheimer A $\beta$ peptide: Identification of Properties Distinctive for Toxic Prefibrillar Species. ISBN 978-91-7519-930-6 (Licentiate thesis) Linköping University

54. Madelen Bodin (2012) Computational problem solving in university physics education

- Students' beliefs, knowledge, and motivation. ISBN 978-91-7459-398-3 (Doctoral Dissertation) Umeå University

55. Lena Aretorn (2012) Mathematics in the Swedish Upper Secondary School Electricity Program: A study of teacher knowledge. ISBN 978-91-7459-429-4 (Licentiate thesis) Umeå University 
56. Anders Jidesjö (2012) En problematisering av ungdomars intresse för naturvetenskap och teknik i skola och samhälle - Innehåll, medierna och utbildningens funktion. ISBN 978-91-7519-873-6 (Doctoral Dissertation) Linköping University

57. Thomas Lundblad (2012) Simulerad verklighet i gymnasieskolans fysik: en designstudie om en augmented reality simulering med socio-naturvetenskapligt innehåll. ISBN 978-91-7519-854-5 (Licentiate thesis) Linköping University

58. Annie-Maj Johansson (2012) Undersökande arbetssätt i NO-undervisningen i grundskolans tidigare årskurser. ISBN 978-91-7447-552-4 (Doctoral Dissertation) Stockholm University

59. Anna Jobér (2012) Social Class in Science Class. ISBN 978-91-86295-31-8 (Doctoral Dissertation) Malmö University

60. Jesper Haglund (2012) Analogical reasoning in science education - connections to semantics and scientific modeling in thermodynamics. ISBN 978-91-7519-773-9 (Doctoral Dissertation) Linköping University

61. Fredrik Jeppsson (2012) Adopting a cognitive semantic approach to understand thermodynamics within science education. ISBN 978-91-7519-765-4 (Doctoral Dissertation) Linköping University

62. Maria Petersson (2012) Lärares beskrivningar av evolution som undervisningsinnehåll i biologi på gymnasiet.ISBN 978-91-7063-453-6 (Doctoral Dissertation) Karlstad University

63. Henrik Carlsson (2012) Undervisningsform, klassrumsnormer och matematiska förmågor. En studie av ett lokalt undervisningsförsök för elever med intresse och fallenhet för matematik. ISBN 978-91-86983-89-5 (Licentiate thesis) Linnaeus University)

64. Anna Bergqvist (2012) Models of Chemical Bonding. Representations Used in School Textbooks and by Teachers and their Relation to Students' Understanding. ISBN 97891-7063-463-5 (Licentiate thesis) Karlstad University

65. Nina Kilbrink (2013) Lära för framtiden: Transfer i teknisk yrkesutbildning. ISBN 978-91-7063-478-9 (Doctoral Dissertation) Karlstad University

66. Caroline Larsson (2013) Experiencing Molecular Processes. The Role of Representations for Students' Conceptual Understanding. ISBN 978-91-7519-607-7 (Doctoral Dissertation) Linköping University

67. Anna-Karin Carstensen (2013) Connect Modelling Learning to Facilitate Linking Models and the Real World through Labwork in Electric Circuit Courses for Engineering Students ISBN 978-91-7519-562-9 (Doctoral Dissertation) Linköping University

68. Konferensproceeding: 10-year Anniversary Meeting with the Scientific Committee

69. Marie Bergholm (2014) Gymnasieelevers kommunikativa strategier i matematikklassrummet. En fallstudie av ett smågruppsarbete om derivata ISBN 97891-7519-306-9 (Licentiate thesis) Linköping University

70. Ingrid Lundh (2014) Undervisa Naturvetenskap genom Inquiry - En studie av två högstadielärare. ISBN 978-91-7519-285-7 (Licentiate thesis) Linköping University

71. Nils Boman (2014) Personality traits in fish - implications for invasion biology ISBN:978-91-7601-097-6 (Licentiate thesis) Umeå University

72. Torodd Lunde (2014) När läroplan och tradition möts - lärarfortbildning och syften med undersökande aktiviteter inom den laborativa NO-undervisningen i grundskolans senare del. ISBN: 978-91-7063-577-9 (Licentiate thesis) Karlstad University

73. Martin Eriksson (2014) Att ta ställning - gymnasieelevers argumentation och beslutsfattande om sociovetenskapliga dilemman. ISBN 978-91-7063-588-5 (Licentiate thesis), Karlstad University 
74. Annalena Holm (2014) Mathematics Communication within the Frame of Supplemental Instruction. Identifying Learning Conditions. ISBN 978-91-7623-112-8 (Licentiate thesis) Lund University

75. Daniel Olsson (2014) Young people's 'Sustainability Consciousness' - Effects of ESD implementation in Swedish schools. ISBN 978-91-7063-594-6. (Licentiate thesis) Karlstad University

76. Marlene Sjöberg (2014) Möjligheter I kollegiala samtal om NO-undervisning och bedömning. https://gupea.ub.gu.se/handle/2077/24063 (Licentiate thesis) Gothenburg University.

77. Teresa Berglund (2014) Student 'Sustainability Consciousness' and Decision-Making on Sustainability Dilemmas. Investigating effects of implementing education for sustainable development in Swedish upper secondary schools. ISBN 978-91-7063599-1 (Licentiate thesis) Karlstad University

78. Elisabet Mellroth (2014) High achiever! Always a high achiever? A comparison of student achievements on mathematical tests with different aims and goals. ISBN 97891-7063-607-3 (Licentiate thesis) Karlstad University

79. Jenny Green (2014) Elevers användande av formativ återkoppling i matematik. ISBN 978-91-7519-164-5 (Licentiate thesis) Linköping University

80. Klara Kerekes (2014) Undervisning om växande geometriska mönster-en variationsteoretisk studie om hur lärare behandlar ett matematiskt innehåll på mellanstadiet. ISBN: 978-91-7519-135-5 (Licentiate thesis) Linköping University

81. Cecilia Axell (2015) Barnlitteraturens tekniklandskap: en didaktisk vandring frăn Nils Holgersson till Pettson och Findus. ISBN 978-91-7519-227-7 (Doctoral Dissertation) Linköping University.

82. Jan Forsgren (2015) Synthesis and characterization of catalysts for hydrogen production from water ISBN 978-91-7601-206-2.(Licentiate thesis) Umeå University

83. Maria Eriksson (2015) Att kommunicera naturvetenskap i nationella prov: En studie med andraspråksperspektiv. ISBN 978-91-7519-138-6 (Licentiate thesis) Linköping University

84. Tomas Jemsson (2015) Time correlated single photon spectroscopy on pyramidal quantum dots. ISBN 978-91-7519-143-O (Licentiate thesis) Linköping University

85. Helen Hasslöf (2015) The Challenge of Education for Sustainable Development. Qualification, social change and the political ISBN: 978-91-7519-127-o (Doctoral Dissertation) Linköping University.

86. Johan Sidenvall (2015) Att lära sig resonera - Om elevers möjligheter att lära sig resonera matematiskt. ISBN 978-91-7519-100-3 (Licentiate thesis) Linköping University.

87. Jonas Jäder (2015) Elevers möjligheter till lärande av matematiska resonemang. ISBN 978-91-7519-099-0 (Licentiate thesis) Linköping University.

88. Laurence Russell (2015) Exploring systematic lesson variation -a teaching method in mathematics. ISBN 978-91-7519-041-9 (Licentiate thesis) Linköping University.

89. Roger Andersson (2015). Ett lysande experiment. En studie av lärandeprogressionen vid lärande med datorstöd i optik. ISBN 978-91-7485-215-8 (Licentiate thesis) Mälardalen University.

90. Therese Granekull (2015). Kamratbedömning i naturvetenskap på mellanstadiet formativ återkoppling genom gruppsamtal. ISBN: 978-91-86295-74-5 (Licentiate thesis) Malmö högskola.

91. Yukiko Asami-Johansson (2015) Designing Mathematics Lessons Using Japanese Problem Solving Oriented Lesson Structure. A Swedish Case Study. ISBN. 978-917685-990-2 (Licentiate thesis) Linköping University.

92. Katarina Ottander (2015). Gymnasieelevers diskussioner utifrån hållbar utveckling. Meningsskapande, naturkunskapande, demokratiskapande. ISBN 978-91-7601-322-9 (Doctoral Dissertation) Umeå University

93. Lena Heikka (2015) Matematiklärares målkommunikation - En jämförelse av elevernas uppfattningar, lärarens beskrivningar och den realiserade undervisningen. ISBN: 978-91-7583-446-7 (Licentiate thesis) Luleå University of Technology. 
94. Anette Pripp (2016) Välja teknik? Ungdomars röster om valet till gymnasiets teknikprogram. ISBN 978-91-7685-775-5 (Licentiate thesis) Linköping University.

95. Annika Pettersson (2016) Grafisk och algebraisk representation: Gymnasieelevers förståelse av linjära funktioner. ISBN 978-91-7063-705-6 (Licentiate thesis) Karlstad University.

96. Erika Boström (2017) Formativ bedömning: En enkel match eller en svår utmaning? Effekter av en kompetensutvecklingssatsning på lärarnas praktik och på elevernas prestationer i matematik. ISBN 978-91-7601-706-7 (Doctoral Dissertation) Umeå University.

97. Gustav Bohlin (2017) Evolving germs - Antibiotic resistance and natural selection in education and public communication. ISBN: 978-91-7685-489-1 (Doctoral Dissertation) Linköping University.

98. Daniel Åkerblom (2018) Meningsfullhet i lärandet - hur kan autenticitet förändra undervisningspraktiken? ISBN: 978-91-88761-19-4 (Licentiate thesis) Linnaeus University.

99. Charlotta Nordlöf (2018) Tekniklärares attityder till teknikämnet och teknikundervisningen. ISBN 978-91-7685-328-3 (Licentiate thesis) Linköping University.

100. Johan Boström (2018) Teknik i förskolan - att motverka traditionella könsroller - En aktionsforskningsstudie. ISBN 978-91-7685-307-8 (Licentiate thesis) Linköping University

101. Christian Rydberg (2018) Didaktiska dilemman i undervisning utifrån samhällsdilemman ISBN 978-91-86295-78-3 (Licentiate thesis) Malmö University

102. Magnus Jansson (2018) Risken blir ju att det blir mer skola av det”! En studie om teknik på fritidshem ISBN 978-91-7685-272-9 (Licentiate thesis) Linköping University

103. Maria Lindfors (2018) "Kunskap är vad du vet, och vet du inte kan du alltid googla!" Elevers epistemic beliefs i naturvetenskaplig undervisningskontext. ISBN 978-917601-887-3 (Doctoral Dissertation) Umeå University

104. Felix Schultze (2018) Coteaching chemical bonding with Upper secondary senior students - A way to refine teachers' PCK. ISBN 978-91-7685-211-8 (Licentiate thesis) Linköping University

105. Jörgen Stenlund (2018). Travelling through time - Students' interpretation of evolutionary time in dynamic visualizations. ISBN 978-91-7685-121-0 (Licentiate thesis) Linköping University 


\section{FACULTY OF SCIENCE AND ENGINEERING}

Linköping studies in science and technology, Licentiate Thesis No. 1833 Department of Science and Technology

Linköping University

SE-58183 Linköping, Sweden

www.liu.se 